\title{
Orman yangınının ve yangın sonrası boşaltma kesimlerinin toprak özelliklerine etkisi
}

\author{
The effects of forest fire and post-fire salvage logging on soil properties
}

\author{
Aliye Sepken KAPTANOĞLU ${ }^{1}$ \\ Ayten NAMLI ${ }^{2}$
}

'Orman Toprak ve Ekoloji Araştırmaları Enstitüsü Müdürlüğ̈̈̈, Eskişehir

${ }^{2}$ Ankara Üniversitesi, Ziraat Fakültesi, Ankara

Sorumlu yazar (Corresponding author) Aliye Sepken KAPTANOĞLU asepken@gmail.com

Geliş tarihi (Received)

04.06.2018

Kabul Tarihi (Accepted)

22.10.2018

Atıf (To cite this article): KAPTANOĞLU, A NAMLI, A . (2019). Orman yangınının ve yangın sonrası boşaltma kesimlerinin toprak özelliklerine etkisi. Ormancılık Araştırma Dergisi, 6 (1), 29-46

DOI: https://doi.org/10.17568/ogmoad.430649

\section{Giriş}

Creative Commons Atıf Türetilemez 4.0 Uluslarara
Lisansı ile lisanslanmıştır.

\begin{abstract}
Öz
$\mathrm{Bu}$ çalışmada, orman yangının biyokimyasal toprak özellikleri üzerindeki etkilerinin ve yanan ağaçların kesilerek sahadan uzaklaştırılmasının toprağa etkilerinin gösterilmesi amaçlanmıştır. Karadeniz ve İç Anadolu bölgeleri arasında geçit kuşağında yer alan Safranbolu'da (Karabük) yangından sonra tüylü meşe (Quercus pubescens) ve karaçam (Pinus nigra) karışı meşceresi topraklarında kimyasal ve biyolojik özellikler çalışılmıştır. Üç yıl izlenen yanmış (enkazı üzerinde bırakılan, boşaltma kesimleri yapılmış) ve yanmamış orman (kontrol) sahaları için istatistiksel değerlendirme çift yönlü varyans analizine göre, gruplar arası karşılaştırma ise Duncan ve Dunnett T3 post hoc testleri uygulanarak SPSS 21 ile yapılmıştır. Sonuçlar, düşük ve orta şiddetli orman yangınının toprakta bazı kimyasal özellikleri olumlu etkilediğini $\left(\mathrm{pH}, \mathrm{CaCO}_{3}, \mathrm{Ca}, \mathrm{P}_{2} \mathrm{O}_{5}\right)$, bazılarını etkilemediğini ( $\mathrm{EC}, \mathrm{OM}, \mathrm{TN}$, asit fosfataz), bazılarını ise olumsuz etkilediğini ( $\beta$-D glikosidaz, üreaz enzim aktiviteleri) göstermiştir. İncelenen parametreler 1şığında, düşük ve orta şiddetli yangın sonrası bu ormanda yapılan boşaltma çalışmalarının ise toprak özelliklerinin iyileşmesine olumsuz bir etkisi tespit edilmemiştir.
\end{abstract}

Anahtar kelimeler: Orman yangını, toprak özellikleri, toprak enzimleri, asit fosfataz, üreaz, Cmic/Corg

\begin{abstract}
In this study, it was aimed to see the effects of wildfire on biochemical properties of soil and the effects of removing the residuals of burned trees on the soil, as well. Chemical and biological properties of soil on oak (Quercus pubescens) and crimean pine (Pinus nigra) mixed sites were studied after a wildfire, in Safranbolu which is in Black SeaCentral Anatolia transition zone. Statistical evaluation for burned (with and without burned trees) and unburned (control) areas monitored for three years was made according to two-way anova analysis, and Duncan and Dunnett T3 post hoc tests were conducted with SPSS 21. The results indicated that low- and moderate-intensity forest fire had positive effects on some chemical properties of soil $\left(\mathrm{pH}, \mathrm{CaCO}_{3}\right.$, $\mathrm{Ca}, \mathrm{P}_{2} \mathrm{O}_{5}$ ) while it had no effects on some of them (EC, OM, TN, acid phosphatase, ) or had negative effects ( $\beta$-D glucosidase, urease enzyme activities) on others. In the light of analyzed parameters, it was not detected any negative effects of salvage logging works in the forests, after a low- and moderate-intensity fire, on the improvement of soil properties.
\end{abstract}

Keywords: Forest fire, soil properties, soil enzymes, acid phosphatase, urease, $\mathrm{Cmic} / \mathrm{Corg}$

Yangın ve toprak arasında karşıyangının toprak üzerine ve toprak üstü biyokütleye olan etkisi yanında toprağa etkileri göz ardı lıklı bir ilişki bulunmaktadır ve edilse de, yoğunluk, şiddeti ve 
sıklığına bağlı olarak uzun ve kısa süreli pek çok önemli etkisi vardır (Certini, 2005; Bilgili, 2009; Certini, 2013). Toprağın yangından sonra kendini toparlama kapasitesi; sahanın yangın geçmişi, topoğrafyası, yangın sonrası hava koşulları, vejetesyon yenilenme süreci (Caon ve ark., 2014; Francos ve ark., 2018) ve yangın sonrası yönetim etkinliklerine bağlıdır (Pereira ve ark., 2018).

Ülkemizde doğal ve denetimli yangınların toprağ1n fiziksel ve kimyasal yapısı üzerine etkilerinin çalışıldığ 1 pek çok çalışma mevcuttur (Eron, 1977; Eron ve Gürbüzer, 1988; Neyişçi, 1989; Neyişçi ve ark., 2002; Kantarcı ve ark., 1986; Boydak ve ark., 1996; Gürlevik ve ark., 2009; Tavşanoğlu ve Gürkan, 2010; Y1ldız ve ark., 2010). Daha az olmakla birlikte toprağın biyolojik özelliklerinin incelendiği çalışmalar da mevcuttur, ancak yapılan araştırmalardan (Turgay ve ark., 2002; Küçük, 2006; Kara ve Bolat, 2009; Berber ve ark., 2015; Akburak ve ark., 2017) anlaşılmıştır ki yangın sonrası mikrobiyal etkinlik ve ayrışma üzerine genellemeler yapılabilmesi için bu konuda daha fazla bilimsel çalışmaya ihtiyaç vardır. Mikrobiyal etkinlikler üzerine yangının kısa ve uzun dönemli etkilerinin araştırılması, orman ekosistemlerinde yangının rolünün daha iyi anlaşılmasını sağlayacaktır.

$\mathrm{Bu}$ çalışmada biyolojik parametreler kullanılarak düşük-orta şiddetli bir orman yangınının ve yangın sonrası boşaltma kesimlerinin toprak üzerine etkilerinin ortaya konması amaçlanmıştır.

\section{Materyal ve Metod}

Araştırmamız, Zonguldak Orman Bölge Müdürlüğü, Karabük İşletme Müdürlüğü, Safranbolu Şefliği hudutlarında Bulak Mağarası mevkiinde yer alan yükseltisi 720-760 m, güney bakılı, 9-10 Ekim 2011'de piknik ateşinin sebep olduğu, 5 ha büyüklüğünde yangına maruz kalmış sahada yürütülmüştür. Söz konusu çalışma sahası, meşcere planında $\mathrm{Çkab}_{3}$ çağında fiiliyatta tüylü meşe ( $Q u$ ercus pubescens Wild.) ve karaçam (Pinus nigra Arnld. subsp. Pallasiana (Lamb.) Holmboe) kar1ş1k meşeceresi ile 3 kapalılıkta yanmamış komşu alanı kapsayan bir ağaçlandırma sahasıdır (1974-

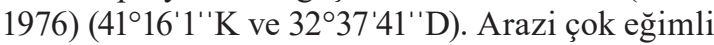
ve yamaç arazi yapısındadır. Çok taşı ı ve kayalık olan sahada anakaya kireçtaşı-marndır.

Tüylü meşe ve karaçam türlerinde, her türde yanmış bölme kısmında dokuz örnek alan, kontrol sahasında yapı aynı olduğundan her türde üçer alan çevrilerek toprak örnekleri alınmıştır. Örnek alanların yarısı kadarı rutin müdahalelere ve kalan kısmı da hiçbir müdahale görmeyecek şekilde ayrılmıştır ve toprağın üç yıllık zaman zarfında, mevsimsel olarak kimyasal ve biyolojik değişim incelemeleri yapılmıştır.

Yangın şiddeti, toprak yüzeyinde mevcut yakıt miktarına, O horizonundaki incelme miktarına ve küllerin beyazlaşıp beyazlaşmamasına göre tahmin edilmiştir (Bentley ve Fenner, 1958; Kara ve Bolat, 2009). Sahanın büyük çoğunluğunda siyah külün ve çıplak toprak yüzeyinin hâkim olduğu görülmüştür. Buna göre yangının hafif ve orta şiddette olduğu tahmin edilmiştir.

Saha topraklarından tepkimelerin nötr-hafif alkali özellikte, tuzsuz ve kireç içeriklerinin profil derinliğince yüksek olduğu belirlenmiştir. Yüzey horizonunda oldukça yüksek olan organik madde içeriği alt derinliğe doğru düşüktür. Toprak tekstürü killi-balçık sınıfındadır. Kireçli ana materyal üzerinde yer alan topraklar A-C horizonludur. Bu özellikleri ile topraklar; intrazonal ordosu, kalsimorfik alt ordosunda olup büyük toprak grubu rendzina olarak tanımlanmıştır (Anon, 2014a; Anon, 2014b).

Toprak örneklemesi meşe ve karaçam türleri altında, yangından hemen sonra ilk ay içinde (A1), üçüncü ay (A3), altınc1 ay (A6), dokuzuncu ay (A9), on ikinci ay (A12), yirmi dördüncü ay (A24) ve son olarak üçüncü yıl dönümünde yani otuz altıncı ayda (A36) yapılmıştır. Derinlik kademeleri 0-7,5 cm (üst derinlik) ve 7,5-15 cm (alt derinlik) olarak belirlenmiştir. Değerlendirmeler ilk iki dönem yangın sahası (enkazlı) ve kontrol sahasında yapılmıştır. Rutin bir yönetim etkinliği olarak, yangının ilk yılında ilkbaharda sahada boşaltma kesimi yapılmış olup bazı örnek alanlar enkazlı saha olarak ayrılmış ve değerlendirmeler, A6, A9, A12, A24 ve A36 dönemlerinde enkazı üzerinde bırakılan sahalarda (EY), boşaltma kesimi yapılarak enkazı kaldırılan sahalarda (BY) ve kontrol (K) sahalarında yapılmıştır. Enkazlı bırakılan ve boşaltılmış sahalar arasındaki farklar uygulamanın etkisi olarak değerlendirilmiştir.

Toprağın kimyasal analizleri için araziden alınıp ayrılan toprak örnekleri hava kurusu hâline geldikten sonra öğütülüp 2 mm'lik elekten geçirilmiştir. Öğütülen toprakların bir kısmı $105^{\circ} \mathrm{C}$ 'de sabit ağırlığa kadar kurutulduktan sonra tartılmış, ve bu toprakların nem içerikleri belirlenmiştir. Kalan örneklerde organik madde, $\mathrm{pH}, \mathrm{EC}$, toplam kireç $\left(\mathrm{CaCO}_{3}\right)$, toplam azot (TN), yarayışlı fosfor $\left(\mathrm{P}_{2} \mathrm{O}_{5}\right)$ ve kalsiyum(Ca) analizleri yapılmış ve organik karbon hesaplama yoluyla belirlenmiştir.

Toprak reaksiyonu $(\mathrm{pH}) ; 1 / 2,5$ oranında saf suda (Jackson, 1962) saturasyon ekstraktında cam elektrotlu pH metre ile (Richards, 1954), elektriksel iletkenlik $\left(\mathrm{EC} 25^{\circ} \mathrm{C}\right)$; conductivity bridge cihazı 
kullanılarak suyla doygun toprak ekstraktında kondüktümetrik yönteme göre (Jackson, 1962), toplam kireç; scheibler kalsimetresi ile (Gülçur, 1974), Ca; $\mathrm{NH}_{4} \mathrm{OAc}$ ekstarktında atomik absorpsiyon spektrometre ile (Kaçar, 2009), organik madde; toprak örneklerinde belirlenen organik karbonun Van Bemmelen faktörüyle çarpılarak hesaplama ile (OCx1,724) organik karbon tayini; Walkley-Black yaş yakma yöntemiyle (Gülçur, 1974) alınabilir fosfor; asit reaksiyonlu topraklarda amonyum florür, alkalen reaksiyonlu topraklarda sodyum bikarbonat yöntemine göre Spectronic 20D kolorimetre cihazında (Ülgen ve Ateşalp, 1972), toplam N; Sömi-Mikro Kjeldahl yöntemine göre (Jackson, 1962; Irmak, 1953), Kjeltec Auto 1030 cihazında tayin edilmiştir.
Biyolojik analizlerde ise $\mathrm{C}, \mathrm{N}$ ve $\mathrm{P}$ döngüsünde görev alan toprak enzimleri; betaglikosidaz, üreaz ve asit fosfataz tayin edilmiş ve $\mathrm{Cmic} / \mathrm{Corg}$ oranı tespit edilmiştir. Toprak $\beta$-D Glikosidaz ve Asit Fosfataz Enzim Aktivitesi Naseby ve Lynch'in (1997) bildirdiği şekilde, üreaz aktivitesi ise Hoffman ve Teicher'e (1961) göre analiz edilmiştir. Cmic/Corg tayini; toprağın mikrobiyal biyokütle karbon değerinin organik karbona bölünmesiyle belirlenmiştir. $\mathrm{Bu}$ oranda kullanılan $\mathrm{Cmic}$ analizi, kloroform fumigasyon-ekstraksiyon metoduna göre (Vance ve ark., 1987) ekstraktlar Shimadzu TOC-L analyzer cihazında okunarak yapılmıştır.

Sayısal veriler $n$, Ortalama \pm Standart sapma $(\mathrm{Sd})$ biçiminde verilmiştir. Sonuçlar; yangının, uygula-

Tablo 1a. Örnekleme dönemlerindeki ortalama pH değerleri

Table 1a. Mean soil pH levels within the sampling period

\begin{tabular}{|c|c|c|c|c|c|c|c|c|c|}
\hline \multirow{2}{*}{$\begin{array}{c}\text { Toprak } \\
\text { özellikleri } \\
\end{array}$} & \multirow[b]{2}{*}{ Uyg. } & \multicolumn{2}{|c|}{ A1 } & \multicolumn{2}{|c|}{ A3 } & \multicolumn{2}{|c|}{ A6 } & \multicolumn{2}{|c|}{ A9 } \\
\hline & & $\mathrm{M}$ & Çk & $\mathrm{M}$ & Çk & $\mathrm{M}$ & Çk & $\mathrm{M}$ & Çk \\
\hline \multirow{10}{*}{$\mathrm{pH}$} & $\mathrm{K}_{\text {ust }}$ & $6,6 \pm 0,3^{*}$ & $6,0 \pm 0,3$ & $6,6 \pm 0,3$ & $6,2 \pm 0,2$ & $6,4 \pm 0,2$ & $6,4 \pm 0,1$ & $6,6 \pm 0,1$ & $6,0 \pm 0,3$ \\
\hline & $\mathrm{K}_{\mathrm{alt}}$ & $6,9 \pm 0,3$ & $5,8 \pm 0,5$ & $6,7 \pm 0,1$ & $6,1 \pm 0,6$ & $6,4 \pm 0,6$ & $6,3 \pm 0,4$ & $6,7 \pm 0,1$ & $5,9 \pm 0,2$ \\
\hline & $\mathrm{K}_{\text {ort }}$ & $6,8 \pm 0,3$ & $5,9 \pm 0,4$ & $6,7 \pm 0,2$ & $6,2 \pm 0,4$ & $6,4 \pm 0,4$ & $6,4 \pm 0,3$ & $6,7 \pm 0,1$ & $5,9 \pm 0,3$ \\
\hline & $E Y_{\text {üst }}$ & $7,1 \pm 0,2$ & $6,7 \pm 0,3$ & $7,0 \pm 0,2$ & $6,7 \pm 0,4$ & $7,2 \pm 0,2$ & $7,2 \pm 0,3$ & $7,3 \pm 0,1$ & $7,2 \pm 0,2$ \\
\hline & $\mathrm{EY}_{\text {alt }}$ & $7,0 \pm 0,4$ & $6,6 \pm 0,4$ & $7,1 \pm 0,3$ & $6,6 \pm 0,6$ & $7,4 \pm 0,2$ & $7,1 \pm 0,2$ & $7,4 \pm 0,2$ & $7,3 \pm 0,2$ \\
\hline & $\mathrm{EY}_{\text {ort }}$ & $7,0 \pm 0,3$ & $6,7 \pm 0,4$ & $7,1 \pm 0,2$ & $6,6 \pm 0,5$ & $7,3 \pm 0,2$ & $7,1 \pm 0,2$ & $7,3 \pm 0,1$ & $7,2 \pm 0,2$ \\
\hline & $B Y_{\text {üst }}$ & & & & & $7,4 \pm 0,1$ & $6,9 \pm 0,4$ & $7,5 \pm 0,2$ & $6,9 \pm 0,4$ \\
\hline & $\mathrm{BY}_{\text {alt }}$ & & & & & $7,3 \pm 0,2$ & $6,5 \pm 0,7$ & $7,5 \pm 0,1$ & $6,6 \pm 0,4$ \\
\hline & $\mathrm{BY}_{\text {ort }}$ & & & & & $7,3 \pm 0,1$ & $6,7 \pm 0,6$ & $7,5 \pm 0,2$ & $6,8 \pm 0,4$ \\
\hline & Ort. & $7,0 \pm 0,3$ & $6,5 \pm 0,5$ & $7,0 \pm 0,9$ & $6,5 \pm 0,5$ & $7,1 \pm 0,5$ & $6,8 \pm 0,5$ & $7,2 \pm 0,3$ & $6,7 \pm 0,6$ \\
\hline
\end{tabular}

M: meşe (Quercus pubescens), Çk: karaçam (Pinus nigra), M: oak, Çk: crimean pine , ${ }^{*}$ Ortalama \pm standart sapma ${ }^{*}$ Mean \pm standart deviation

Tablo 1b. Örnekleme dönemlerindeki ortalama $\mathrm{pH}$ değerleri

Table 1b. Mean soil pH levels within the sampling period

\begin{tabular}{|c|c|c|c|c|c|c|c|c|c|}
\hline \multirow{2}{*}{$\begin{array}{l}\text { Toprak } \\
\text { özellikleri }\end{array}$} & \multirow{2}{*}{ Uyg. } & \multicolumn{2}{|c|}{ A12 } & \multicolumn{2}{|c|}{ A24 } & \multicolumn{2}{|c|}{ A 36} & \multicolumn{2}{|c|}{ Toplam ortalama } \\
\hline & & M & Çk & M & Çk & M & Çk & M & Çk \\
\hline \multirow{10}{*}{$\mathrm{pH}$} & $\mathrm{K}_{\text {üst }}$ & $6,6 \pm 0,1$ & $6,1 \pm 0,2$ & $6,2 \pm 0,8$ & $6,1 \pm 0,5$ & $6,4 \pm 0,9$ & $6,4 \pm 1,0$ & $6,5 \pm 0,4$ & $6,2 \pm 0,4$ \\
\hline & $\mathrm{K}_{\text {alt }}$ & $6,8 \pm 0,1$ & $5,8 \pm 0,2$ & $6,1 \pm 0,9$ & $6,0 \pm 0,8$ & $6,4 \pm 1,3$ & $6,9 \pm 0,3$ & $6,6 \pm 0,6$ & $6,1 \pm 0,5$ \\
\hline & $\mathrm{K}_{\text {ort }}$ & $6,7 \pm 0,1$ & $6,0 \pm 0,2$ & $6,1 \pm 0,7$ & $6,0 \pm 0,6$ & $6,4 \pm 1,0$ & $6,7 \pm 0,7$ & $6,5 \pm 0,5$ & $6,1 \pm 0,5$ \\
\hline & $\mathrm{EY}_{\text {ust }}$ & $7,4 \pm 0,2$ & $7,1 \pm 0,4$ & $7,3 \pm 0,1$ & $7,1 \pm 0,4$ & $7,4 \pm 0,1$ & $7,1 \pm 0,2$ & $7,2 \pm 0,2$ & $7,0 \pm 0,4$ \\
\hline & $\mathrm{EY}_{\mathrm{alt}}$ & $7,4 \pm 0,1$ & $7,1 \pm 0,3$ & $7,3 \pm 0,1$ & $7,2 \pm 0,4$ & $7,4 \pm 0,1$ & $7,3 \pm 0,2$ & $7,2 \pm 0,3$ & $6,9 \pm 0,5$ \\
\hline & $\mathrm{EY}_{\mathrm{ort}}$ & $7,4 \pm 0,2$ & $7,1 \pm 0,3$ & $7,3 \pm 0,1$ & $7,2 \pm 0,4$ & $7,4 \pm 0,1$ & $7,2 \pm 0,2$ & $7,2 \pm 0,2$ & $7,0 \pm 0,4$ \\
\hline & $B Y_{\text {üst }}$ & $7,5 \pm 0,1$ & $7,2 \pm 0,2$ & $7,4 \pm 0,1$ & $6,8 \pm 0,5$ & $7,2 \pm 0,1$ & $7,0 \pm 0,4$ & $7,4 \pm 0,2$ & $7,0 \pm 0,4$ \\
\hline & $B Y_{\text {alt }}$ & $7,4 \pm 0,1$ & $6,9 \pm 0,5$ & $7,4 \pm 0,0$ & $6,9 \pm 0,4$ & $7,2 \pm 0,1$ & $7,2 \pm 0,4$ & $7,4 \pm 0,1$ & $6,8 \pm 0,5$ \\
\hline & $\mathrm{BY}_{\text {ort }}$ & $7,5 \pm 0,1$ & $7,0 \pm 0,4$ & $7,4 \pm 0,1$ & $6,9 \pm 0,4$ & $7,2 \pm 0,1$ & $7,1 \pm 0,4$ & $7,4 \pm 0,2$ & $6,9 \pm 0,4$ \\
\hline & Ort. & $7,3 \pm 0,3$ & $6,8 \pm 0,6$ & $7,0 \pm 0,6$ & $6,8 \pm 0,6$ & $7,1 \pm 0,6$ & $7,0 \pm 0,5$ & $7,1 \pm 0,5$ & $6,73 \pm 0,5$ \\
\hline
\end{tabular}


manın (boşaltma kesimlerinin), dönemin (A6, A9, A12, A24 ve A36'da), türün (meşe ve karaçamda) ve derinliğin (üst-alt toprak derinliklerinde) etkisini gösteren istatistiki bulgular 1şığında değerlendirilmiştir. Veriler normal dağılım gösterdiğinde tek yönlü varyans analizi, normal dağılım göstermediğinde veya varyanslar homojen olmadığında ise Kruskall Wallis testi uygulanmıştır. K, EY ve BY alan grupları arasındaki farklar dağılım normal ve eşit varyanslı olduğunda Duncan testi ile gruplandırılmış, farklı varyans durumunda ise Dunnett T3 testiyle değerlendirilmiştir (Özdamar, 2004).

\section{Bulgular}

Meşe ve karaçam üst topraklarında yangın ile toprak reaksiyonunun çok önemli düzeyde $\operatorname{arttığ~}$ belirlenmiştir $(\mathrm{P}<0,001)$. Meşe üst topraklarında üç grup birbirinden önemli düzeyde farklı tespit edilmiştir $(\mathrm{P}<0,01)$. Meşe ve karaçamda dönemin $\mathrm{pH}$ üzerine etkisinin de istatistiksel olarak önemli olduğu görülmüştür $(\mathrm{P}<0,05)$. Türlerin $\mathrm{pH}$ üzerinde- ki etkisi $\mathrm{P}<0,001$ düzeyinde önemli iken meşe türü altı topraklarında toprak reaksiyonunun önemli düzeyde yüksek olduğu anlaşılmıştır (Tablo 1a, b). Her iki türde de derinlik toprak reaksiyonu üzerinde etkili bulunmamıştır.

Meşe ve karaçam topraklarında yangının toprak kireç kapsamı üzerine etkisi önemli bulunmuştur ( $\mathrm{P}$ $=0,000)$. Enkazlı ve boşaltılmış yangın sahalarının $\mathrm{CaCO}_{3}$ bakımından önemli düzeyde fark göstermediği, ancak kontrol grubunun her iki türde ve derinlikte de yangın sahalarından önemli düzeyde farklı olduğu anlaşılmıştır. Örnekleme döneminin toprağın $\mathrm{CaCO}_{3}$ kapsamı üzerindeki etkisi meşe üst topraklarında önemli düzeydedir. Kireç oranının en yüksek olduğu dönem meşede A24 iken en düşük olduğu dönem A6 olarak bulunmuştur (Tablo 2a, b). $\mathrm{CaCO}_{3}$, tür farklılığgndan çok önemli düzeyde etkilenmiştir $(\mathrm{P}<0,001)$; meşenin altından alınan toprak örneklerindeki $\mathrm{CaCO}_{3}$, karaçamın altından alınanlara göre önemli ölçüde yüksektir. $\mathrm{CaCO}_{3}$ değerleri derinlik bakımından istatistiksel olarak farklı değildir.

Tablo 2a. Örnekleme dönemlerindeki ortalama $\mathrm{CaCO}_{3}$ değerleri

Table 2a. Mean soil $\mathrm{CaCO}_{3}$ levels within the sampling period

\begin{tabular}{|c|c|c|c|c|c|c|c|c|c|}
\hline \multirow{2}{*}{$\begin{array}{c}\text { Toprak } \\
\text { özellikleri }\end{array}$} & \multirow{2}{*}{ Uyg. } & \multicolumn{2}{|c|}{ A1 } & \multicolumn{2}{|c|}{ A3 } & \multicolumn{2}{|c|}{ A6 } & \multicolumn{2}{|c|}{ A9 } \\
\hline & & M & Çk & $\mathrm{M}$ & Çk & M & Çk & $\mathrm{M}$ & Çk \\
\hline \multirow{10}{*}{$\begin{array}{c}\mathrm{CaCO} 3 \\
\%\end{array}$} & $\mathrm{~K}_{\text {üst }}$ & $1,3 \pm 0,9$ & $0,0 \pm 0,0$ & $2,1 \pm 0,5$ & $0,8 \pm 0,8$ & $0,0 \pm 0,0$ & $0,0 \pm 0,0$ & $0,8 \pm 0,0$ & $0,0 \pm 0,0$ \\
\hline & $\mathrm{K}_{\mathrm{alt}}$ & $2,3 \pm 2,0$ & $0,0 \pm 0,0$ & $2,6 \pm 0,4$ & $1,3 \pm 0,4$ & $0,0 \pm 0,0$ & $0,0 \pm 0,0$ & $0,5 \pm 0,5$ & $0,0 \pm 0,0$ \\
\hline & $\mathrm{K}_{\mathrm{ort}}$ & $1,8 \pm 1,5$ & $1,2 \pm 1,0$ & $2,3 \pm 0,5$ & $1,0 \pm 0,6$ & $0,0 \pm 0,0$ & $0,0 \pm 0,0$ & $0,6 \pm 0,3$ & $0,0 \pm 0,0$ \\
\hline & $\mathrm{EY}_{\text {ust }}$ & $1,9 \pm 0,9$ & $1,4 \pm 0,6$ & $2,4 \pm 1,3$ & $1,5 \pm 0,7$ & $2,3 \pm 1,1$ & $1,7 \pm 2,1$ & $2,8 \pm 1,9$ & $1,7 \pm 0,3$ \\
\hline & $\mathrm{EY}_{\text {alt }}$ & $2,7 \pm 1,0$ & $1,6 \pm 0,9$ & $3,0 \pm 1,6$ & $2,3 \pm 1,4$ & $4,2 \pm 1,8$ & $2,5 \pm 4,1$ & $3,5 \pm 2,4$ & $3,2 \pm 1,6$ \\
\hline & $\mathrm{EY}_{\text {ort }}$ & $2,3 \pm 1,0$ & $0,0 \pm 0,0$ & $2,7 \pm 1,4$ & $1,9 \pm 1,2$ & $3,3 \pm 1,8$ & $2,1 \pm 3,1$ & $3,2 \pm 2,1$ & $2,5 \pm 1,3$ \\
\hline & $\mathrm{BY}_{\text {usst }}$ & & & & & $1,9 \pm 1,3$ & $0,4 \pm 0,8$ & $4,6 \pm 2,3$ & $1,3 \pm 1,0$ \\
\hline & $\mathrm{BY}_{\text {alt }}$ & & & & & $2,1 \pm 0,9$ & $0,7 \pm 1,5$ & $5,6 \pm 2,8$ & $0,8 \pm 0,6$ \\
\hline & $\mathrm{BY}_{\mathrm{ort}}$ & & & & & $2,0 \pm 1,1$ & $0,6 \pm 1,1$ & $5,1 \pm 2,4$ & $1,1 \pm 0,8$ \\
\hline & Ort. & $2,2 \pm 1,2$ & $1,5 \pm 0,7$ & $2,6 \pm 1,2$ & $1,7 \pm 1,1$ & $2,0 \pm 1,8$ & $1,1 \pm 2,2$ & $3,2 \pm 2,5$ & $1,4 \pm 1,4$ \\
\hline
\end{tabular}

Tablo 2b. Örnekleme dönemlerindeki ortalama $\mathrm{CaCO}_{3}$ değerleri

Table 2b. Mean soil $\mathrm{CaCO}_{3}$ levels within the sampling period

\begin{tabular}{cccccccccc}
\hline \multirow{2}{*}{$\begin{array}{c}\text { Toprak } \\
\text { özellikleri }\end{array}$} & Uyg. & \multicolumn{2}{c}{ A12 } & \multicolumn{2}{c}{ A24 } & \multicolumn{2}{c}{ A36 } & \multicolumn{3}{c}{ Toplam ortalama } \\
\cline { 3 - 9 } & & $\mathrm{M}$ & Çk & $\mathrm{M}$ & Çk & $\mathrm{M}$ & Çk & $\mathrm{M}$ & Çk \\
\hline & $\mathrm{K}_{\text {ust }}$ & $3,6 \pm 1,2$ & $0,0 \pm 0,0$ & $1,8 \pm 3,1$ & $0,0 \pm 0,0$ & $0,6 \pm 0,6$ & $0,3 \pm 0,2$ & $1,4 \pm 1,6$ & $0,1 \pm 0,4$ \\
& $\mathrm{~K}_{\text {alt }}$ & $3,0 \pm 0,8$ & $0,0 \pm 0,0$ & $1,8 \pm 3,1$ & $1,5 \pm 2,6$ & $0,6 \pm 0,5$ & $0,6 \pm 0,7$ & $1,5 \pm 1,6$ & $0,5 \pm 1,1$ \\
& $\mathrm{~K}_{\text {ort }}$ & $3,3 \pm 0,9$ & $0,0 \pm 0,0$ & $1,8 \pm 2,7$ & $0,8 \pm 1,9$ & $1,0 \pm 0,5$ & $0,4 \pm 0,5$ & $1,5 \pm 1,6$ & $0,3 \pm 0,8$ \\
$\mathrm{CaCO} 3$ & $\mathrm{EY}_{\text {ust }}$ & $5,5 \pm 2,1$ & $3,0 \pm 1,2$ & $5,7 \pm 1,8$ & $7,6 \pm 4,0$ & $1,4 \pm 0,7$ & $1,7 \pm 1,4$ & $2,9 \pm 2,0$ & $2,4 \pm 2,5$ \\
$\%$ & $\mathrm{EY}_{\text {alt }}$ & $4,6 \pm 1,4$ & $3,6 \pm 1,3$ & $6,0 \pm 2,2$ & $8,3 \pm 5,4$ & $2,5 \pm 0,9$ & $3,8 \pm 4,2$ & $3,6 \pm 1,9$ & $3,3 \pm 3,3$ \\
& $\mathrm{EY}_{\text {ort }}$ & $5,0 \pm 1,8$ & $3,4 \pm 1,3$ & $5,8 \pm 1,9$ & $8,0 \pm 4,5$ & $2,0 \pm 1,0$ & $2,8 \pm 3,2$ & $3,3 \pm 2,0$ & $2,9 \pm 3,0$ \\
& $\mathrm{BY}_{\text {ust }}$ & $5,6 \pm 3,6$ & $2,3 \pm 1,2$ & $7,1 \pm 5,7$ & $4,2 \pm 1,3$ & $1,4 \pm 0,4$ & $1,6 \pm 2,3$ & $4,1 \pm 3,6$ & $2,0 \pm 1,8$ \\
& $\mathrm{BY}_{\text {alt }}$ & $7,5 \pm 4,1$ & $2,7 \pm 1,8$ & $7,8 \pm 6,1$ & $4,6 \pm 1,9$ & $2,0 \pm 1,1$ & $2,9 \pm 3,2$ & $5,0 \pm 4,1$ & $2,3 \pm 2,3$ \\
& $\mathrm{BY}_{\text {ort }}$ & $6,5 \pm 3,7$ & $2,5 \pm 1,5$ & $7,5 \pm 5,5$ & $4,4 \pm 1,5$ & $1,7 \pm 0,8$ & $2,3 \pm 2,8$ & $4,6 \pm 3,8$ & $2,2 \pm 2,0$ \\
& Ort. & $5,1 \pm 2,7$ & $2,2 \pm 1,8$ & $5,4 \pm 4,1$ & $5,0 \pm 4,3$ & $1,5 \pm 1,0$ & $2,0 \pm 2,7$ & $3,1 \pm 2,7$ & $2,1 \pm 2,6$ \\
\hline
\end{tabular}


Meşe ve karaçamda Ca miktarı yangınla beraber önemli düzeyde artış göstermiştir $(\mathrm{P}<0,001)$. Meşede en düşük değerini kontrol sahasında (2634 $\mathrm{mg} / \mathrm{kg}$ ) alan $\mathrm{Ca}$ en yüksek değerini boşaltılmış yangın sahasında-BY (3802 mg/kg) almıştır. Karaçamda ise kontrol sahasında $1759 \mathrm{mg} / \mathrm{kg}$ olan Ca değeri BY sahasında $2690 \mathrm{mg} / \mathrm{kg}$ 'a yükselmiştir (Tablo 3a, b). Enkazlı ve boşaltılmış yangın sahaları arasında $\mathrm{CaCO}_{3}$ oranında olduğu gibi, Ca miktarı bakımından da önemli düzeyde fark olmadığ ancak kontrol grubunun her iki türde ve derinlikte yangın sahalarından önemli düzeyde farklı olduğu bulunmuştur. Ca ortalamalarındaki artış yangınla beraber kireç miktarındaki artış ile paralellik göstermektedir. Türlerin ise Ca miktarı üzerinde etkisi çok önemli düzeydedir $(\mathrm{P}<0,001)$. Meşede ortalama $3486 \mathrm{mg} / \mathrm{kg}$ olan Ca miktarı karaçamda ortalama $2423 \mathrm{mg} / \mathrm{kg}$ 'a düşmektedir (Tablo 3a, b). Örnekleme döneminin ve toprak derinliğinin karaçam ve meşede Ca miktarı üzerinde önemli düzeyde etkisinin olmadığ 1 anlaşılmıştır $(\mathrm{P}>0,05)$.

Tablo 3a. Örnekleme dönemlerindeki ortalama Ca değerleri

Table 3a. Mean soil Ca levels within the sampling period

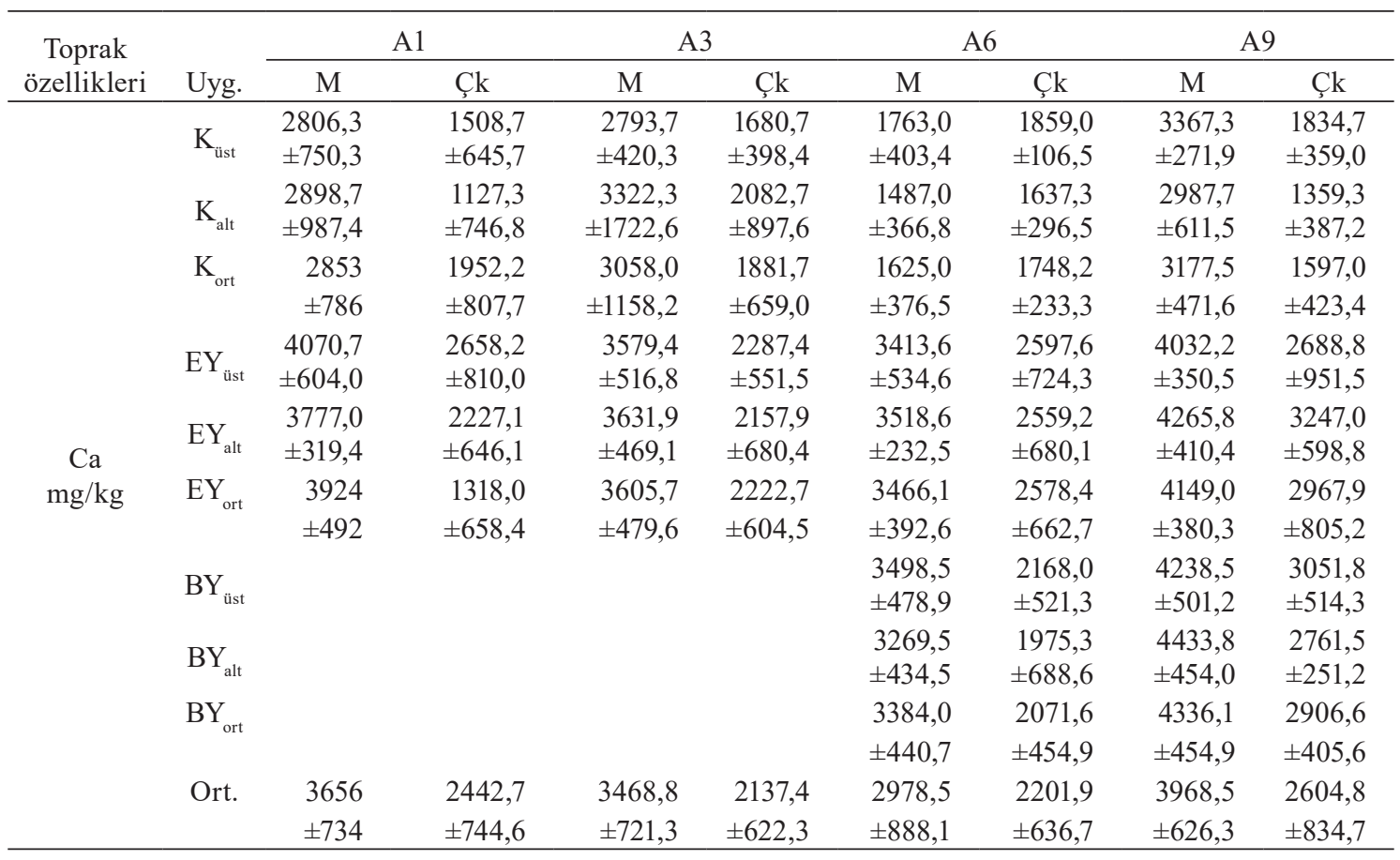

Meşede ve karaçamda yangının $\mathrm{P}_{2} \mathrm{O}_{5}$ üzerine önemli düzeyde etkili olduğu ve yangınla beraber toprağın yarayışlı fosfor düzeylerinin arttığı belirlenmiştir. Her iki türde ve derinlikte EY ile BY sahaları arasında fark bulunmazken yangın sahalarının kontrol sahalarından önemli düzeyde farklı olduğu ve daha fazla $\mathrm{P}_{2} \mathrm{O}_{5}$ içerdiği tespit edilmiştir (Tablo 4a, b). Örnekleme döneminin toprağın $\mathrm{P}_{2} \mathrm{O}_{5}$ kapsamı üzerine etkisinin her iki türde de önemli düzeyde bulunmadığ 1 görülmüştür $(\mathrm{P}>0,05)$.

Ağaç türü toprağın yarayışlı fosforu üzerinde çok önemli düzeyde etkili bulunmuştur $(\mathrm{P}<0,001)$. Meşenin hâkim olduğu topraklarda $\mathrm{P}_{2} \mathrm{O}_{5}$ içeriğinin karaçamdan yüksek olduğu görülmüştür. Derinliğin ise her iki türde yarayışlı fosfor üzerine önemli düzeyde etkili olduğu bulunmuştur. Üst derinlik örneklerinde ortalama $\mathrm{P}_{2} \mathrm{O}_{5}$ değerleri daha yüksek ölçülmüştür.
Yangının elektriksel iletkenlik üzerine etkisi meşede önemsiz $(\mathrm{P}>0,05)$ karaçamda ise önemli düzeyde bulunmuştur $(\mathrm{P}=0,001)$. Örnekleme döneminin hem meşe hem de karaçam topraklarında EC üzerine önemli düzeyde etkili olduğu belirlenmiştir $(\mathrm{P}<0,001)$. En yüksek EC ortalaması yangından hemen sonrası alınan yani A1 toprak örneklerinde (meşede $1,0 \mathrm{mS} / \mathrm{cm}$, karaçamda $0,8 \mathrm{mS} / \mathrm{cm}$ ); en düşük ortalama A6 örneklerinde (meşe ve karaçamda 0,4 $\mathrm{mS} / \mathrm{cm}$ ) ölçülmüştür (Tablo 5a, b). Ağaç türlerinin EC üzerindeki etkisinin çok önemli düzeyde bulunduğu görülmüştür $(\mathrm{P}<0,001)$. Meşe türü altından alınan toprak örneklerinde elektriksel iletkenliğin önemli düzeyde yüksek olduğu anlaşılmıştır. Elektriksel iletkenlik üzerine derinliğin etkisi meşe ve karaçam topraklarında $\mathrm{P}<0,05$ düzeyinde önemli bulunmuştur.

Toprağın organik madde miktarı meşede ve karaçamda her iki derinlikte de yangından önemli dü- 
Tablo 3b. Örnekleme dönemlerindeki ortalama Ca değerleri

Table 3b. Mean soil Ca levels within the sampling period

\begin{tabular}{|c|c|c|c|c|c|c|c|c|c|}
\hline \multirow{2}{*}{$\begin{array}{c}\text { Toprak } \\
\text { özellikleri }\end{array}$} & \multirow[b]{2}{*}{ Uyg. } & \multicolumn{2}{|c|}{ A12 } & \multicolumn{2}{|c|}{ A24 } & \multicolumn{2}{|c|}{ A 36} & \multicolumn{2}{|c|}{ Toplam ortalama } \\
\hline & & M & Çk & M & Çk & M & Çk & M & Çk \\
\hline \multirow{14}{*}{$\begin{array}{c}\mathrm{Ca} \\
\mathrm{mg} / \mathrm{kg}\end{array}$} & $\mathrm{K}_{\text {ust }}$ & $\begin{array}{l}3930,3 \\
\pm 732,4\end{array}$ & $\begin{array}{l}2032,7 \\
\pm 699,3\end{array}$ & $\begin{array}{l}2373,0 \\
\pm 194,1\end{array}$ & $\begin{array}{r}2133,7 \\
\pm 698,3\end{array}$ & $\begin{array}{r}2313,0 \\
\pm 1243,0\end{array}$ & $\begin{array}{l}1366,3 \\
\pm 561,0\end{array}$ & $\begin{array}{l}2763,8 \\
\pm 878,8\end{array}$ & $\begin{array}{r}1773,7 \\
\pm 518,3\end{array}$ \\
\hline & $\mathrm{K}_{\mathrm{alt}}$ & $\begin{array}{l}2889,0 \\
\pm 474,5\end{array}$ & $\begin{array}{l}1450,7 \\
\pm 756,6\end{array}$ & $\begin{array}{l}2182,3 \\
\pm 433,5\end{array}$ & $\begin{array}{r}2539,3 \\
\pm 1820,4\end{array}$ & $\begin{array}{r}1765,7 \\
\pm 1279,4\end{array}$ & $\begin{array}{r}2019,7 \\
\pm 934,5\end{array}$ & $\begin{array}{r}2504,7 \\
\pm 1041,0\end{array}$ & $\begin{array}{r}1745,2 \\
\pm 923,8\end{array}$ \\
\hline & $\mathrm{K}_{\text {ort }}$ & 3409,7 & 1741,7 & 2277,7 & 2336,5 & 2039,3 & 1693,0 & 2634,2 & 1759,4 \\
\hline & & $\pm 793,7$ & $\pm 725,4$ & 318,0 & $\pm 1253,0$ & $\pm 1167,3$ & $\pm 776,7$ & $\pm 960,5$ & $\pm 740,0$ \\
\hline & $E Y_{\text {ust }}$ & $\begin{array}{l}3534,4 \\
\pm 186,7\end{array}$ & $\begin{array}{r}2917,6 \\
\pm 1067,7\end{array}$ & $\begin{array}{l}3605,0 \\
\pm 260,5\end{array}$ & $\begin{array}{l}2915,2 \\
\pm 754,7\end{array}$ & $\begin{array}{l}3878,0 \\
\pm 419,2\end{array}$ & $\begin{array}{l}2808,0 \\
\pm 537,7\end{array}$ & $\begin{array}{l}3748,1 \\
\pm 497,0\end{array}$ & $\begin{array}{l}2654,6 \\
\pm 747,0\end{array}$ \\
\hline & $\mathrm{EY}_{\text {alt }}$ & $\begin{array}{l}3620,0 \\
\pm 173,2\end{array}$ & $\begin{array}{r}2670,4 \\
\pm 864,2\end{array}$ & $\begin{array}{l}3666,8 \\
\pm 323,3\end{array}$ & $\begin{array}{l}2907,2 \\
\pm 855,4\end{array}$ & $\begin{array}{l}3934,8 \\
\pm 303,6\end{array}$ & $\begin{array}{l}3007,0 \\
\pm 620,7\end{array}$ & $\begin{array}{r}3760,7 \\
\pm 390,0\end{array}$ & $\begin{array}{l}2591,1 \\
\pm 759,3\end{array}$ \\
\hline & $\mathrm{EY}_{\text {ort }}$ & 3577,2 & 2794,0 & 3635,9 & 2911,2 & 3906,4 & 2907,5 & 3754,4 & 2622,9 \\
\hline & & $\pm 175,6$ & $\pm 925,0$ & 278,7 & $\pm 760,5$ & $\pm 346,4$ & $\pm 557,4$ & $\pm 444,1$ & $\pm 749,4$ \\
\hline & $B Y_{\text {ust }}$ & $\begin{array}{l}3807,3 \\
\pm 573,2\end{array}$ & $\begin{array}{l}2562,3 \\
\pm 158,6\end{array}$ & $\begin{array}{l}3636,3 \\
\pm 671,5\end{array}$ & $\begin{array}{r}2557,3 \\
\pm 482,6\end{array}$ & $\begin{array}{l}3793,5 \\
\pm 606,6\end{array}$ & $\begin{array}{r}3523,0 \\
\pm 2636,7\end{array}$ & $\begin{array}{l}3794,8 \\
\pm 567,7\end{array}$ & $\begin{array}{r}2772,5 \\
\pm 1205,9\end{array}$ \\
\hline & $\mathrm{BY}_{\text {alt }}$ & $\begin{array}{l}3928,8 \\
\pm 202,7\end{array}$ & $\begin{array}{l}2653,8 \\
\pm 680,5\end{array}$ & $\begin{array}{l}3670,5 \\
\pm 469,1\end{array}$ & $\begin{array}{l}2756,3 \\
\pm 671,7\end{array}$ & $\begin{array}{l}3743,5 \\
\pm 474,8\end{array}$ & $\begin{array}{l}2899,3 \\
\pm 771,5\end{array}$ & $\begin{array}{l}3809,2 \\
\pm 539,1\end{array}$ & $\begin{array}{l}2609,2 \\
\pm 659,8\end{array}$ \\
\hline & $\mathrm{BY}_{\text {ort }}$ & 3868,0 & 2608,0 & 3653,4 & 2656,8 & 3768,5 & 3211,1 & 3802,0 & 2690,8 \\
\hline & & $\pm 403,3$ & $\pm 460,0$ & $\pm 536,6$ & $\pm 551,8$ & $\pm 505,0$ & $\pm 1829,2$ & $\pm 546,5$ & $\pm 963,0$ \\
\hline & Ort. & 3632,3 & 2468,9 & 3302,2 & 2682,7 & 3393,7 & 2705,1 & 3485,7 & 2423,2 \\
\hline & & $\pm 481,7$ & $\pm 839,2$ & 710,7 & $\pm 845,3$ & $\pm 1030,8$ & $\pm 1282,6$ & $\pm 800,1$ & $\pm 886,2$ \\
\hline
\end{tabular}

Tablo 4a. Örnekleme dönemlerindeki ortalama $\mathrm{P}_{2} \mathrm{O}_{5}$ değerleri Table $4 \mathrm{a}$. Mean soil $\mathrm{P}_{2} \mathrm{O}_{5}$ levels within the sampling period

\begin{tabular}{|c|c|c|c|c|c|c|c|c|c|}
\hline \multirow{2}{*}{$\begin{array}{c}\text { Toprak } \\
\text { özellikleri }\end{array}$} & \multirow{2}{*}{ Uyg. } & \multicolumn{2}{|c|}{ A1 } & \multicolumn{2}{|c|}{ A3 } & \multicolumn{2}{|c|}{ A6 } & \multicolumn{2}{|c|}{ A9 } \\
\hline & & M & Çk & M & Çk & $\mathrm{M}$ & Çk & $\mathrm{M}$ & Çk \\
\hline \multirow{10}{*}{$\begin{array}{c}\mathrm{P}_{2} \mathrm{O}_{5} \\
\mathrm{mg} / \mathrm{kg}\end{array}$} & $\mathrm{K}_{\text {üst }}$ & $20,0 \pm 13$ & $10,7 \pm 3$ & $9,3 \pm 1$ & $7,7 \pm 2$ & $7,0 \pm 4$ & $7,0 \pm 4$ & $7,7 \pm 1$ & $6,7 \pm 1$ \\
\hline & $\mathrm{K}_{\text {alt }}$ & $16,7 \pm 12$ & $8,3 \pm 1$ & $7,0 \pm 2$ & $6,7 \pm 1$ & $2,7 \pm 2$ & $4,3 \pm 1$ & $5,3 \pm 2$ & $4,7 \pm 2$ \\
\hline & $\mathrm{K}_{\text {ort }}$ & $18,3 \pm 11$ & $12,4 \pm 7$ & $8,2 \pm 2$ & $7,2 \pm 1$ & $4,8 \pm 4$ & $5,7 \pm 3$ & $6,5 \pm 2$ & $5,7 \pm 2$ \\
\hline & $\mathrm{EY}_{\text {üst }}$ & $42,6 \pm 12$ & $33,8 \pm 20$ & $27,6 \pm 9$ & $17,9 \pm 9$ & $57,0 \pm 19$ & $58,8 \pm 19$ & $35,4 \pm 9$ & $29,6 \pm 19$ \\
\hline & $\mathrm{EY}_{\text {alt }}$ & $21,6 \pm 10$ & $13,8 \pm 8$ & $18,0 \pm 11$ & $8,0 \pm 1$ & $25,0 \pm 2$ & $22,2 \pm 4$ & $24,6 \pm 11$ & $28,0 \pm 31$ \\
\hline & $\mathrm{EY}_{\mathrm{ort}}$ & $32,1 \pm 15$ & $9,5 \pm 2$ & $22,8 \pm 11$ & $12,9 \pm 8$ & $41,0 \pm 21$ & $40,5 \pm 23$ & $30,0 \pm 11$ & $28,8 \pm 24$ \\
\hline & $\mathrm{BY}_{\text {üst }}$ & & & & & $63,3 \pm 3$ & $24,5 \pm 25$ & $29,0 \pm 9$ & $31,8 \pm 26$ \\
\hline & $\mathrm{BY}_{\text {alt }}$ & & & & & $26,8 \pm 9$ & $9,5 \pm 9$ & $26,5 \pm 12$ & $12,3 \pm 6$ \\
\hline & $\mathrm{BY}_{\text {ort }}$ & & & & & $45,0 \pm 20$ & $17,0 \pm 19$ & $27,8 \pm 10$ & $22,0 \pm 20$ \\
\hline & Ort. & $28,6 \pm 15$ & $23,8 \pm 18$ & $19,1 \pm 11$ & $11,5 \pm 8$ & $33,3 \pm 24$ & $24,0 \pm 23$ & $23,4 \pm 13$ & $20,8 \pm 21$ \\
\hline
\end{tabular}

zeyde etkilenmemiştir $(\mathrm{P}>0,05)$. EY ve BY sahaları ile $\mathrm{K}$ sahaları her iki türde ve her iki derinlikte aynı grupta yer almış ve içerdikleri organik madde bakımından gruplar arasında önemli bir fark bulunmadığı tespit edilmiştir. Meşede organik madde en fazla kontrol sahasında $(\% 5,96)$ ve en düşük BY sahasında $(\% 4,97)$ bulunmuştur. Karaçamda da değişim aynı yöndedir. Örnekleme döneminin sadece meşede toprağın organik madde kapsamı üzerine etkisinin önemli düzeyde olduğu görülmüştür. Organik madde miktarının en yüksek seviyesi yang1nın ardından alınan topraklarda (A1) gözlenmiştir (Tablo 6a, b). Türler arasında ise toprak organik madde içeriği bakımından çok önemli düzeyde fark bulunmuştur. Meşe topraklarında organik madde içeriğinin daha fazla olduğu görülmüştür (M: \%5,56 ve Çk: \%4,48). Toprak derinliği her iki türde de organik madde düzeyini önemli ölçüde etkilemiştir. Her iki türde de üst topraklarda ortalamalar daha yüksektir (Tablo 6a, b).

Hem meşe hem karaçamda yangın ve dönemin toprağın toplam azot kapsamı üzerine etkisinin önemli düzeyde olmadığ 1 görülmüştür $(\mathrm{P}>0,05)$. EY, BY ve K sahalarının her üçü de farklı türlerde ve derinliklerde aynı grupta yer almıştır. Ortalamalara bakıldığında yangınla beraber azot miktarında artış olduğu görülmekle birlikte (Tablo $7 \mathrm{a}, \mathrm{b}$ ) azot ba- 
Tablo 4b. Örnekleme dönemlerindeki ortalama $\mathrm{P}_{2} \mathrm{O}_{5}$ değerleri

Table 4b. Mean soil $\mathrm{P}_{2} \mathrm{O}_{5}$ levels within the sampling period

\begin{tabular}{ccrrrrrrrr}
\hline \multirow{2}{*}{$\begin{array}{c}\text { Toprak } \\
\text { özellikleri }\end{array}$} & Uyg. & \multicolumn{1}{c}{$\mathrm{M}$} & \multicolumn{1}{c}{ Çk } & \multicolumn{1}{c}{$\mathrm{M}$} & \multicolumn{1}{c}{ Çk } & \multicolumn{1}{c}{$\mathrm{M}$} & \multicolumn{1}{c}{ Çk } & \multicolumn{1}{c}{ M } & \multicolumn{1}{c}{ Çk } \\
\cline { 3 - 10 } & $\mathrm{K}_{\text {ust }}$ & $7,3 \pm 1$ & $1,0 \pm 0$ & $7,8 \pm 2$ & $4,6 \pm 0$ & $8,9 \pm 2$ & $4,5 \pm 1$ & $9,7 \pm 6$ & $6,0 \pm 3$ \\
& $\mathrm{~K}_{\text {alt }}$ & $1,3 \pm 1$ & $1,7 \pm 1$ & $4,7 \pm 1$ & $3,5 \pm 0$ & $8,8 \pm 7$ & $9,3 \pm 9$ & $6,6 \pm 7$ & $5,5 \pm 4$ \\
& $\mathrm{~K}_{\text {ort }}$ & $4,3 \pm 3$ & $1,3 \pm 1$ & $6,3 \pm 2$ & $4,0 \pm 1$ & $8,9 \pm 4$ & $6,9 \pm 6$ & $8,2 \pm 7$ & $5,8 \pm 4$ \\
& $\mathrm{EY}_{\text {ust }}$ & $33,2 \pm 7$ & $26,6 \pm 23$ & $29,7 \pm 10$ & $17,5 \pm 9$ & $22,6 \pm 7$ & $13,2 \pm 7$ & $35,4 \pm 14$ & $27,8 \pm 20$ \\
$\mathrm{P}_{2} \mathrm{O}_{5}$ & $\mathrm{EY}_{\text {alt }}$ & $24,6 \pm 12$ & $14,6 \pm 13$ & $18,8 \pm 6$ & $34,3 \pm 47$ & $17,7 \pm 3,9$ & $13,9 \pm 3,2$ & $21,2 \pm 9$ & $17,7 \pm 20$ \\
$\mathrm{mg} / \mathrm{kg}$ & $\mathrm{EY}_{\text {ort }}$ & $28,9 \pm 11$ & $20,6 \pm 18$ & $24,3 \pm 10$ & $25,9 \pm 33$ & $20,1 \pm 6$ & $13,6 \pm 5$ & $28,3 \pm 14$ & $22,7 \pm 21$ \\
& $\mathrm{BY}_{\text {ust }}$ & $50,5 \pm 16$ & $21,5 \pm 9$ & $27,3 \pm 11$ & $13,5 \pm 12$ & $25,6 \pm 7$ & $18,7 \pm 13$ & $39,1 \pm 18$ & $22,0 \pm 17$ \\
& $\mathrm{BY}_{\text {alt }}$ & $37,8 \pm 17$ & $18,5 \pm 15$ & $19,4 \pm 8$ & $9,2 \pm 8$ & $19,5 \pm 3$ & $14,8 \pm 10$ & $26,0 \pm 12$ & $12,8 \pm 10$ \\
& $\mathrm{BY}$ & $44,1 \pm 17$ & $20,0 \pm 12$ & $23,4 \pm 10$ & $11,3 \pm 10$ & $22,5 \pm 6$ & $16,8 \pm 11$ & $32,6 \pm 16$ & $17,4 \pm 15$ \\
& Ort. & $27,8 \pm 19$ & $15,6 \pm 16$ & $19,5 \pm 11$ & $15,6 \pm 23$ & $18,1 \pm 8$ & $13,0 \pm 8$ & $24,3 \pm 16$ & $17,2 \pm 18$ \\
\hline
\end{tabular}

Tablo 5a. Örnekleme dönemlerindeki ortalama EC değerleri

Table 5a. Mean soil EC levels within the sampling period

\begin{tabular}{cccccccccc}
\hline \multirow{2}{*}{$\begin{array}{c}\text { Toprak } \\
\text { özellikleri }\end{array}$} & Uyg. & $\mathrm{M}$ & Çk & $\mathrm{A}$ & Çk & $\mathrm{M}$ & Çk & $\mathrm{M}$ & Çk \\
\cline { 3 - 9 } & $\mathrm{K}_{\text {ust }}$ & $1,0 \pm 0,3$ & $0,6 \pm 0,3$ & $0,6 \pm 0,1$ & $0,5 \pm 0,1$ & $0,4 \pm 0,0$ & $0,4 \pm 0,0$ & $1,0 \pm 0,1$ & $0,6 \pm 0,2$ \\
& $\mathrm{~K}_{\text {alt }}$ & $0,8 \pm 0,5$ & $0,4 \pm 0,3$ & $0,5 \pm 0,1$ & $0,4 \pm 0,1$ & $0,3 \pm 0,0$ & $0,4 \pm 0,0$ & $1,0 \pm 0,2$ & $0,5 \pm 0,1$ \\
& $\mathrm{~K}_{\text {ort }}$ & $0,9 \pm 0,4$ & $0,7 \pm 0,3$ & $0,6 \pm 0,1$ & $0,4 \pm 0,1$ & $0,4 \pm 0,1$ & $0,4 \pm 0,1$ & $1,0 \pm 0,2$ & $0,6 \pm 0,1$ \\
& $\mathrm{EY}_{\text {ust }}$ & $1,1 \pm 0,1$ & $0,9 \pm 0,1$ & $0,8 \pm 0,2$ & $0,5 \pm 0,1$ & $0,5 \pm 0,1$ & $0,4 \pm 0,1$ & $0,7 \pm 0,1$ & $0,7 \pm 0,2$ \\
$\mathrm{EC}$ & $\mathrm{EY}_{\text {alt }}$ & $0,9 \pm 0,1$ & $0,7 \pm 0,3$ & $0,7 \pm 0,2$ & $0,5 \pm 0,1$ & $0,4 \pm 0,1$ & $0,4 \pm 0,1$ & $0,6 \pm 0,2$ & $0,6 \pm 0,2$ \\
$10^{3} 25^{\circ} \mathrm{C}$ & $\mathrm{EY}_{\text {ort }}$ & $1,0 \pm 0,2$ & $0,5 \pm 0,3$ & $0,8 \pm 0,2$ & $0,5 \pm 0,1$ & $0,4 \pm 0,1$ & $0,4 \pm 0,1$ & $0,7 \pm 0,2$ & $0,6 \pm 0,2$ \\
$\mathrm{mS} / \mathrm{cm}$ & $\mathrm{BY}_{\text {ust }}$ & & & & & $0,5 \pm 0,0$ & $0,3 \pm 0,1$ & $0,7 \pm 0,1$ & $0,6 \pm 0,2$ \\
& $\mathrm{BY}_{\text {alt }}$ & & & & & $0,5 \pm 0,1$ & $0,3 \pm 0,0$ & $0,6 \pm 0,2$ & $0,6 \pm 0,2$ \\
& $\mathrm{BY}_{\text {ort }}$ & & & & & $0,5 \pm 0,1$ & $0,3 \pm 0,1$ & $0,7 \pm 0,2$ & $0,6 \pm 0,2$ \\
& Ort. & $1,0 \pm 0,2$ & $0,8 \pm 0,2$ & $0,7 \pm 0,2$ & $0,5 \pm 0,1$ & $0,4 \pm 0,1$ & $0,4 \pm 0,1$ & $0,8 \pm 0,2$ & $0,6 \pm 0,2$ \\
\hline
\end{tabular}

Tablo 5b. Örnekleme dönemlerindeki ortalama EC değerleri

Table 5b. Mean soil EC levels within the sampling period

\begin{tabular}{|c|c|c|c|c|c|c|c|c|c|}
\hline \multirow{2}{*}{$\begin{array}{c}\text { Toprak } \\
\text { özellikleri }\end{array}$} & \multirow[b]{2}{*}{ Uyg. } & \multicolumn{2}{|c|}{ A12 } & \multicolumn{2}{|c|}{ A24 } & \multicolumn{2}{|c|}{ A36 } & \multicolumn{2}{|c|}{ Toplam ortalama } \\
\hline & & $\mathrm{M}$ & Çk & $\mathrm{M}$ & Çk & $\mathrm{M}$ & Çk & $\mathrm{M}$ & Çk \\
\hline \multirow{10}{*}{$\begin{array}{c}\mathrm{EC} \\
10^{3} 25^{0} \mathrm{C} \\
\mathrm{mS} / \mathrm{cm}\end{array}$} & $\mathrm{K}_{\text {üst }}$ & $1,2 \pm 0,2$ & $0,7 \pm 0,1$ & $0,5 \pm 0,1$ & $0,5 \pm 0,3$ & $0,2 \pm 0,1$ & $0,1 \pm 0,1$ & $0,7 \pm 0,4$ & $0,5 \pm 0,2$ \\
\hline & $\mathrm{K}_{\text {alt }}$ & $0,9 \pm 0,3$ & $0,5 \pm 0,0$ & $0,4 \pm 0,2$ & $0,4 \pm 0,2$ & $0,2 \pm 0,1$ & $0,2 \pm 0,1$ & $0,6 \pm 0,4$ & $0,4 \pm 0,2$ \\
\hline & $\mathrm{K}_{\text {ort }}$ & $1,0 \pm 0,3$ & $0,6 \pm 0,2$ & $0,5 \pm 0,1$ & $0,4 \pm 0,2$ & $0,2 \pm 0,1$ & $0,1 \pm 0,1$ & $0,6 \pm 0,4$ & $0,4 \pm 0,2$ \\
\hline & $\mathrm{EY}_{\text {üst }}$ & $0,7 \pm 0,1$ & $0,7 \pm 0,1$ & $0,6 \pm 0,0$ & $0,5 \pm 0,2$ & $0,2 \pm 0,0$ & $0,2 \pm 0,2$ & $0,7 \pm 0,3$ & $0,6 \pm 0,3$ \\
\hline & $\mathrm{EY}_{\text {alt }}$ & $0,6 \pm 0,1$ & $0,6 \pm 0,1$ & $0,6 \pm 0,2$ & $0,5 \pm 0,1$ & $0,2 \pm 0,0$ & $0,2 \pm 0,0$ & $0,6 \pm 0,3$ & $0,5 \pm 0,2$ \\
\hline & $\mathrm{EY}_{\text {ort }}$ & $0,7 \pm 0,1$ & $0,7 \pm 0,1$ & $0,6 \pm 0,1$ & $0,5 \pm 0,2$ & $0,2 \pm 0,0$ & $0,2 \pm 0,1$ & $0,7 \pm 0,3$ & $0,5 \pm 0,2$ \\
\hline & $\mathrm{BY}_{\text {usst }}$ & $0,8 \pm 0,1$ & $0,6 \pm 0,1$ & $0,5 \pm 0,1$ & $0,5 \pm 0,1$ & $0,2 \pm 0,0$ & $0,2 \pm 0,1$ & $0,5 \pm 0,2$ & $0,4 \pm 0,2$ \\
\hline & $\mathrm{BY}_{\text {alt }}$ & $0,7 \pm 0,2$ & $0,6 \pm 0,1$ & $0,6 \pm 0,2$ & $0,5 \pm 0,1$ & $0,2 \pm 0,0$ & $0,2 \pm 0,1$ & $0,5 \pm 0,2$ & $0,4 \pm 0,2$ \\
\hline & $\mathrm{BY}_{\mathrm{ort}}$ & $0,8 \pm 0,1$ & $0,6 \pm 0,1$ & $0,6 \pm 0,2$ & $0,5 \pm 0,1$ & $0,2 \pm 0,0$ & $0,2 \pm 0,1$ & $0,5 \pm 0,2$ & $0,4 \pm 0,2$ \\
\hline & Ort. & $0,8 \pm 0,2$ & $0,6 \pm 0,1$ & $0,6 \pm 0,2$ & $0,5 \pm 0,2$ & $0,2 \pm 0,0$ & $0,2 \pm 0,1$ & $0,6 \pm 0,3$ & $0,5 \pm 0,2$ \\
\hline
\end{tabular}

k1mından topraklar istatistiksel olarak farklı değildir. Toprak derinliğinin toplam $\mathrm{N}$ kapsamı üzerine etkisi çok önemli bulunmuştur $(\mathrm{P}<0,001)$. Toplam azot ortalamaları her iki türde de üst topraklarda daha yüksektir. Toplam azot içeriği bakımından iki türün önemli düzeyde farklı olduğu anlaşılmıştır $(\mathrm{P}<0,001)$. Karaçam türü topraklarında azot içeriği meşeden düşük bulunmuştur (Tablo 7a, b).

$\beta$-D glikosidaz enzim aktivitesi yangından, derinlikten ve dönemden önemli düzeyde etkilenmiştir $(\mathrm{P}<0,001)$. $\beta$-D glikosidaz aktivitesinin yangınla beraber önemli ölçüde azaldığı bulunmuştur (Tablo 8a, b). EY sahaları meşe üst topraklarında K'den 
Tablo 6a. Örnekleme dönemlerindeki ortalama OM değerleri

Table 6a. Mean soil OM levels within the sampling period

\begin{tabular}{|c|c|c|c|c|c|c|c|c|c|}
\hline \multirow{2}{*}{$\begin{array}{c}\text { Toprak } \\
\text { özellikleri }\end{array}$} & \multirow[b]{2}{*}{ Uyg. } & \multicolumn{2}{|c|}{ A1 } & \multicolumn{2}{|c|}{ A3 } & \multicolumn{2}{|c|}{ A6 } & \multicolumn{2}{|c|}{ A9 } \\
\hline & & $\mathrm{M}$ & Çk & M & Çk & M & Çk & M & Çk \\
\hline \multirow{10}{*}{$\begin{array}{c}\mathrm{OM} \\
\%\end{array}$} & $\mathrm{~K}_{\text {ust }}$ & $9,4 \pm 2,8$ & $6,3 \pm 1,6$ & $9,7 \pm 1,0$ & $6,1 \pm 2,1$ & $5,1 \pm 1,0$ & $7,1 \pm 1,3$ & $6,6 \pm 1,3$ & $6,6 \pm 1,4$ \\
\hline & $\mathrm{K}_{\text {alt }}$ & $5,9 \pm 3,3$ & $4,2 \pm 2,6$ & $4,6 \pm 1,6$ & $4,0 \pm 0,5$ & $3,6 \pm 0,3$ & $3,8 \pm 1,2$ & $4,9 \pm 1,9$ & $3,6 \pm 0,6$ \\
\hline & $\mathrm{K}_{\text {ort }}$ & $7,65 \pm 3,3$ & $6,32 \pm 1,7$ & $7,16 \pm 3,1$ & $5,05 \pm 1,8$ & $4,34 \pm 1,1$ & $5,42 \pm 2,1$ & $5,76 \pm 1,7$ & $5,09 \pm 1,9$ \\
\hline & $\mathrm{EY}_{\text {üst }}$ & $9,1 \pm 2,4$ & $7,6 \pm 1,6$ & $8,1 \pm 2,0$ & $6,8 \pm 1,9$ & $7,7 \pm 2,8$ & $5,1 \pm 1,8$ & $4,8 \pm 1,7$ & $4,7 \pm 1,4$ \\
\hline & $\mathrm{EY}_{\text {alt }}$ & $5,7 \pm 1,5$ & $4,5 \pm 0,9$ & $5,2 \pm 1,6$ & $3,8 \pm 0,8$ & $3,8 \pm 0,6$ & $2,7 \pm 0,4$ & $3,5 \pm 1,6$ & $4,0 \pm 2,1$ \\
\hline & $\mathrm{EY}_{\text {ort }}$ & $7,42 \pm 2,6$ & $7,61 \pm 1,6$ & $6,64 \pm 2,3$ & $5,3 \pm 2,1$ & $5,73 \pm 2,8$ & $3,87 \pm 1,8$ & $4,15 \pm 1,7$ & $4,34 \pm 1,7$ \\
\hline & $B Y_{\text {ust }}$ & & & & & $7,8 \pm 1,1$ & $5,2 \pm 0,8$ & $4,5 \pm 2,1$ & $5,8 \pm 2,3$ \\
\hline & $\mathrm{BY}_{\text {alt }}$ & & & & & $4,4 \pm 1,6$ & $2,9 \pm 0,8$ & $3,9 \pm 1,0$ & $3,7 \pm 1,5$ \\
\hline & $\mathrm{BY}_{\mathrm{ort}}$ & & & & & $6,10 \pm 2,2$ & $4,07 \pm 1,4$ & $4,20 \pm 1,6$ & $4,79 \pm 2,1$ \\
\hline & Ort. & $7,48 \pm 2,7$ & $7,28 \pm 1,7$ & $6,77 \pm 2,5$ & $5,23 \pm 2,0$ & $5,51 \pm 2,3$ & $4,32 \pm 1,8$ & $4,57 \pm 1,8$ & $4,68 \pm 1,8$ \\
\hline
\end{tabular}

Tablo 6b. Örnekleme dönemlerindeki ortalama OM değerleri Table 6b. Mean soil OM levels within the sampling period

\begin{tabular}{|c|c|c|c|c|c|c|c|c|c|}
\hline \multirow{2}{*}{$\begin{array}{c}\text { Toprak } \\
\text { özellikleri }\end{array}$} & \multirow[b]{2}{*}{ Uyg. } & \multicolumn{2}{|c|}{ A12 } & \multicolumn{2}{|c|}{ A24 } & \multicolumn{2}{|c|}{ A36 } & \multicolumn{2}{|c|}{ Toplam ortalama } \\
\hline & & $\mathrm{M}$ & Çk & $\mathrm{M}$ & Çk & $\mathrm{M}$ & Çk & $\mathrm{M}$ & Çk \\
\hline \multirow{10}{*}{$\begin{array}{c}\mathrm{OM} \\
\%\end{array}$} & $\mathrm{~K}_{\text {üst }}$ & $10,8 \pm 2,3$ & $6,0 \pm 1,5$ & $6,6 \pm 0,8$ & $5,7 \pm 1,4$ & $6,1 \pm 1,8$ & $3,0 \pm 0,3$ & $7,8 \pm 2,5$ & $5,8 \pm 1,8$ \\
\hline & $\mathrm{K}_{\text {alt }}$ & $4,2 \pm 1,4$ & $4,2 \pm 1,5$ & $3,3 \pm 0,1$ & $4,5 \pm 2,7$ & $2,5 \pm 0,4$ & $2,3 \pm 0,8$ & $4,2 \pm 1,8$ & $3,8 \pm 1,5$ \\
\hline & $\mathrm{K}_{\text {ort }}$ & $7,51 \pm 4,0$ & $5,06 \pm 1,7$ & $4,97 \pm 1,9$ & $5,14 \pm 2,0$ & $4,31 \pm 2,1$ & $2,65 \pm 0,6$ & $5,96 \pm 2,8$ & $4,81 \pm 1,9$ \\
\hline & $\mathrm{EY}_{\text {ust }}$ & $6,0 \pm 0,5$ & $5,4 \pm 2,1$ & $4,9 \pm 2,3$ & $4,1 \pm 1,4$ & $4,0 \pm 1,0$ & $3,6 \pm 2,3$ & $6,8 \pm 2,7$ & $5,7 \pm 2,2$ \\
\hline & $\mathrm{EY}_{\text {alt }}^{\text {ust }}$ & $4,4 \pm 1,3$ & $3,6 \pm 1,0$ & $4,8 \pm 1,9$ & $2,7 \pm 0,9$ & $2,8 \pm 0,8$ & $1,8 \pm 0,9$ & $4,5 \pm 1,6$ & $3,5 \pm 1,3$ \\
\hline & $\mathrm{EY}_{\text {ort }}$ & $5,18 \pm 1,3$ & $4,52 \pm 1,8$ & $4,83 \pm 2,0$ & $3,42 \pm 1,4$ & $3,4 \pm 1,0$ & $2,71 \pm 1,9$ & $5,65 \pm 2,5$ & $4,57 \pm 2,1$ \\
\hline & $\mathrm{BY}_{\text {ust }}$ & $7,1 \pm 2,8$ & $4,3 \pm 1,4$ & $5,2 \pm 1,8$ & $4,6 \pm 0,4$ & $4,4 \pm 0,9$ & $3,6 \pm 0,6$ & $5,8 \pm 2,2$ & $4,7 \pm 1,4$ \\
\hline & $\mathrm{BY}_{\text {alt }}$ & $4,3 \pm 1,8$ & $3,3 \pm 0,7$ & $4,8 \pm 2,4$ & $3,3 \pm 0,4$ & $3,3 \pm 0,9$ & $2,6 \pm 0,8$ & $4,2 \pm 1,5$ & $3,2 \pm 0,9$ \\
\hline & $\mathrm{BY}_{\text {ort }}$ & $5,73 \pm 2,6$ & $3,81 \pm 1,2$ & $4,99 \pm 2,0$ & $3,92 \pm 0,8$ & $3,83 \pm 1,0$ & $3,10 \pm 0,8$ & $4,97 \pm 2,1$ & $3,94 \pm 1,4$ \\
\hline & Ort. & $5,95 \pm 2,7$ & $4,42 \pm 1,6$ & $4,92 \pm 1,9$ & $4,02 \pm 1,5$ & $3,77 \pm 1,4$ & $2,82 \pm 1,3$ & $5,56 \pm 2,5$ & $4,48 \pm 1,9$ \\
\hline
\end{tabular}

Tablo 7a. Örnekleme dönemlerindeki ortalama Nt değerleri

Table 7a. Mean soil Nt levels within the sampling period

\begin{tabular}{|c|c|c|c|c|c|c|c|c|c|}
\hline \multirow{2}{*}{$\begin{array}{c}\text { Toprak } \\
\text { özellikleri }\end{array}$} & \multirow[b]{2}{*}{ Uyg. } & \multicolumn{2}{|c|}{ A1 } & \multicolumn{2}{|c|}{ A3 } & \multicolumn{2}{|c|}{ A6 } & \multicolumn{2}{|c|}{ A9 } \\
\hline & & $\mathrm{M}$ & Çk & $\mathrm{M}$ & Çk & $\mathrm{M}$ & Çk & $\mathrm{M}$ & Çk \\
\hline \multirow{10}{*}{$\begin{array}{l}\mathrm{Nt} \\
\%\end{array}$} & $\mathrm{~K}_{\text {üst }}$ & $0,3 \pm 0,1$ & $0,2 \pm 0,1$ & $0,4 \pm 0,1$ & $0,2 \pm 0,1$ & $0,2 \pm 0,0$ & $0,3 \pm 0,1$ & $0,3 \pm 0,0$ & $0,2 \pm 0,0$ \\
\hline & $\mathrm{K}_{\text {alt }}$ & $0,2 \pm 0,1$ & $0,1 \pm 0,0$ & $0,2 \pm 0,1$ & $0,1 \pm 0,0$ & $0,2 \pm 0,0$ & $0,2 \pm 0,0$ & $0,2 \pm 0,1$ & $0,1 \pm 0,0$ \\
\hline & $\mathrm{K}_{\text {ort }}$ & $0,28 \pm 0,1$ & $0,16 \pm 0,1$ & $0,30 \pm 0,1$ & $0,18 \pm 0,1$ & $0,18 \pm 0,0$ & $0,26 \pm 0,1$ & $0,29 \pm 0,1$ & $0,16 \pm 0,0$ \\
\hline & $\mathrm{EY}_{\text {üst }}$ & $0,4 \pm 0,1$ & $0,3 \pm 0,0$ & $0,3 \pm 0,1$ & $0,2 \pm 0,1$ & $0,3 \pm 0,1$ & $0,2 \pm 0,1$ & $0,3 \pm 0,1$ & $0,2 \pm 0,0$ \\
\hline & $\mathrm{EY}_{\text {alt }}$ & $0,2 \pm 0,1$ & $0,2 \pm 0,0$ & $0,2 \pm 0,1$ & $0,1 \pm 0,0$ & $0,2 \pm 0,0$ & $0,1 \pm 0,0$ & $0,2 \pm 0,1$ & $0,2 \pm 0,0$ \\
\hline & $\mathrm{EY}_{\text {ort }}$ & $0,30 \pm 0,2$ & $0,21 \pm 0,1$ & $0,27 \pm 0,1$ & $0,18 \pm 0,1$ & $0,28 \pm 0,1$ & $0,18 \pm 0,1$ & $0,22 \pm 0,1$ & $0,17 \pm 0,0$ \\
\hline & $\mathrm{BY}_{\text {üst }}$ & & & & & $0,4 \pm 0,0$ & $0,2 \pm 0,0$ & $0,2 \pm 0,0$ & $0,3 \pm 0,1$ \\
\hline & $\mathrm{BY}_{\text {alt }}$ & & & & & $0,3 \pm 0,1$ & $0,1 \pm 0,0$ & $0,2 \pm 0,1$ & $0,2 \pm 0,0$ \\
\hline & $\mathrm{BY}_{\mathrm{ort}}$ & & & & & $0,32 \pm 0,1$ & $0,18 \pm 0,1$ & $0,22 \pm 0,1$ & $0,21 \pm 0,1$ \\
\hline & Ort. & $0,29 \pm 0,1$ & $0,2 \pm 0,1$ & $0,28 \pm 0,1$ & $0,18 \pm 0,1$ & $0,27 \pm 0,1$ & $0,20 \pm 0,1$ & $0,24 \pm 0,1$ & $0,18 \pm 0,1$ \\
\hline
\end{tabular}

önemli düzeyde farklı iken BY-EY sahaları arasındaki ve BY-K sahaları arasındaki fark önemli düzeyde değildir. Meşe alt topraklarında yangın sahaları ile kontrol sahaları ise önemli düzeyde farklıdır. Karaçam üst derinlikte ise $\mathrm{K}$ ve EY sa- haları benzer iken $\mathrm{K}$ ve BY sahaları birbirinden farklı bulunmuştur. Örnekleme dönemi bakımından $\beta$-D glikosidaz aktivitesi her iki türde ve derinlikte önemli düzeyde farklıdır. Meşede $(2,06$ mg pNP $\left.\mathrm{h}^{-1} \mathrm{~g}^{-1}\right)$ ve karaçamda $\left(2,81 \mathrm{mg} \mathrm{pNP}^{-1}\right.$ 
Tablo 7b. Örnekleme dönemlerindeki ortalama Nt değerleri

Table $7 \mathrm{~b}$. Mean soil Nt levels within the sampling period

\begin{tabular}{|c|c|c|c|c|c|c|c|c|c|}
\hline \multirow{2}{*}{$\begin{array}{c}\text { Toprak } \\
\text { özellikleri }\end{array}$} & \multirow[b]{2}{*}{ Uyg. } & \multicolumn{2}{|c|}{ A12 } & \multicolumn{2}{|c|}{ A24 } & \multicolumn{2}{|c|}{ A36 } & \multicolumn{2}{|c|}{ Toplam ortalama } \\
\hline & & $\mathrm{M}$ & Çk & M & Çk & M & Çk & M & Çk \\
\hline \multirow{10}{*}{$\begin{array}{l}\mathrm{Nt} \\
\%\end{array}$} & $\mathrm{~K}_{\text {üst }}$ & $0,6 \pm 0,1$ & $0,3 \pm 0,1$ & $0,3 \pm 0,0$ & $0,2 \pm 0,0$ & $0,3 \pm 0,1$ & $0,1 \pm 0,0$ & $0,3 \pm 0,1$ & $0,2 \pm 0,1$ \\
\hline & $\mathrm{K}_{\mathrm{alt}}$ & $0,2 \pm 0,1$ & $0,2 \pm 0,1$ & $0,2 \pm 0,0$ & $0,1 \pm 0,0$ & $0,1 \pm 0,0$ & $0,1 \pm 0,0$ & $0,2 \pm 0,1$ & $0,1 \pm 0,0$ \\
\hline & $\mathrm{K}_{\text {ort }}$ & $0,39 \pm 0,2$ & $0,26 \pm 0,1$ & $0,22 \pm 0,1$ & $0,17 \pm 0,1$ & $0,22 \pm 0,1$ & $0,12 \pm 0,0$ & $0,27 \pm 0,1$ & $0,18 \pm 0,1$ \\
\hline & $\mathrm{EY}_{\text {ust }}$ & $0,3 \pm 0,0$ & $0,3 \pm 0,1$ & $0,2 \pm 0,0$ & $0,2 \pm 0,0$ & $0,2 \pm 0,0$ & $0,2 \pm 0,1$ & $0,3 \pm 0,1$ & $0,2 \pm 0,1$ \\
\hline & $\mathrm{EY}_{\text {alt }}$ & $0,2 \pm 0,1$ & $0,2 \pm 0,1$ & $0,2 \pm 0,0$ & $0,1 \pm 0,0$ & $0,2 \pm 0,0$ & $0,1 \pm 0,0$ & $0,2 \pm 0,1$ & $0,1 \pm 0,0$ \\
\hline & $\mathrm{EY}_{\text {ort }}$ & $0,27 \pm 0,1$ & $0,23 \pm 0,1$ & $0,21 \pm 0,0$ & $0,14 \pm 0,0$ & $0,17 \pm 0,0$ & $0,14 \pm 0,1$ & $0,25 \pm 0,1$ & $0,18 \pm 0,1$ \\
\hline & $\mathrm{BY}_{\text {ust }}$ & $0,4 \pm 0,1$ & $0,2 \pm 0,1$ & $0,3 \pm 0,1$ & $0,2 \pm 0,0$ & $0,2 \pm 0,1$ & $0,2 \pm 0,0$ & $0,3 \pm 0,1$ & $0,2 \pm 0,1$ \\
\hline & $\mathrm{BY}_{\text {alt }}$ & $0,2 \pm 0,1$ & $0,2 \pm 0,0$ & $0,2 \pm 0,1$ & $0,2 \pm 0,0$ & $0,2 \pm 0,0$ & $0,1 \pm 0,0$ & $0,2 \pm 0,1$ & $0,2 \pm 0,0$ \\
\hline & $\mathrm{BY}_{\text {ort }}$ & $0,30 \pm 0,1$ & $0,20 \pm 0,1$ & $0,24 \pm 0,1$ & $0,16 \pm 0,0$ & $0,22 \pm 0,1$ & $0,16 \pm 0,0$ & $0,26 \pm 0,1$ & $0,18 \pm 0,1$ \\
\hline & Ort. & $0,31 \pm 0,1$ & $0,23 \pm 0,1$ & $0,22 \pm 0,1$ & $0,16 \pm 0,0$ & $0,20 \pm 0,1$ & $0,14 \pm 0,1$ & $0,26 \pm 0,1$ & $0,18 \pm 0,1$ \\
\hline
\end{tabular}

$\mathrm{g}^{-1}$ ) üst seviyesine A9'da ulaşmıştır (Tablo 8a, b). Toprak derinliği her iki türde $\beta$-D glikosidaz üzerinde önemli düzeyde etkili bulunmuştur. Meşede üst toprakta $0,88 \mathrm{mg} \mathrm{pNP} \mathrm{h}^{-1} \mathrm{~g}^{-1}$ 'ten alt toprakta

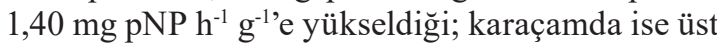

toprakta daha yüksek olduğu (1,60 mg pNP h-1 $\left.\mathrm{g}^{-1}\right)$ tespit edilmiştir.

Meşede asit fosfataz üzerinde dönem $(\mathrm{P}<0,001)$ ve yangın $(\mathrm{P}<0,01)$ etkili bulunmuştur. Meşede en

Tablo 8a. Örnekleme dönemlerindeki ortalama $\beta$-D değerleri

Table 8 a. Mean soil $\beta$-D glucosidase levels within the sampling period

\begin{tabular}{|c|c|c|c|c|c|c|c|c|c|}
\hline \multirow{2}{*}{$\begin{array}{c}\text { Toprak } \\
\text { özellikleri }\end{array}$} & \multirow[b]{2}{*}{ Uyg. } & \multicolumn{2}{|c|}{$\mathrm{A} 1$} & \multicolumn{2}{|c|}{ A3 } & \multicolumn{2}{|c|}{ A6 } & \multicolumn{2}{|c|}{ A9 } \\
\hline & & $\mathrm{M}$ & Çk & $\mathrm{M}$ & $\mathrm{Çk}$ & $\mathrm{M}$ & $\mathrm{Çk}$ & $\mathrm{M}$ & Çk \\
\hline \multirow{10}{*}{$\begin{array}{l}\beta \text {-D Gliko- } \\
\text { sidaz } \\
\text { mg pNP h-1 } \\
\text { g-1 }\end{array}$} & $\mathrm{K}_{\text {ust }}$ & $1,4 \pm 0,7$ & $2,5 \pm 1,2$ & $1,0 \pm 0,7$ & $1,3 \pm 0,4$ & $1,2 \pm 0,2$ & $1,7 \pm 0,1$ & $0,6 \pm 0,5$ & $5,6 \pm 3,0$ \\
\hline & $\mathrm{K}_{\text {alt }}$ & $1,2 \pm 0,8$ & $1,5 \pm 0,2$ & $4,7 \pm 0,3$ & $0,6 \pm 0,1$ & $4,7 \pm 1,5$ & $0,7 \pm 0,1$ & $6,9 \pm 0,5$ & $3,0 \pm 2,1$ \\
\hline & $\mathrm{K}_{\text {ort }}$ & $1,23 \pm 0,6$ & $1,96 \pm 0,9$ & $0,91 \pm 0,5$ & $0,92 \pm 0,5$ & $1,67 \pm 0,9$ & $1,24 \pm 0,6$ & $4,70 \pm 1,0$ & $4,30 \pm 2,7$ \\
\hline & $\mathrm{EY}_{\text {ust }}$ & $0,9 \pm 0,6$ & $1,4 \pm 0,6$ & $0,3 \pm 0,2$ & $1,3 \pm 1,0$ & $0,8 \pm 0,5$ & $1,6 \pm 1,1$ & $0,6 \pm 0,6$ & $2,9 \pm 1,9$ \\
\hline & $\mathrm{EY}_{\text {alt }}$ & $0,4 \pm 0,2$ & $0,6 \pm 0,3$ & $1,2 \pm 0,4$ & $0,5 \pm 0,5$ & $1,1 \pm 0,7$ & $0,6 \pm 0,2$ & $0,6 \pm 0,5$ & $3,1 \pm 2,0$ \\
\hline & $\mathrm{EY}_{\text {ort }}$ & $0,60 \pm 0,5$ & $1,03 \pm 0,6$ & $0,84 \pm 0,8$ & $0,91 \pm 0,8$ & $0,36 \pm 0,2$ & $1,09 \pm 0,9$ & $1,15 \pm 0,6$ & $2,98 \pm 1,9$ \\
\hline & $\mathrm{BY}_{\text {üst }}$ & & & & & $1,3 \pm 1,2$ & $1,0 \pm 0,4$ & $0,7 \pm 0,8$ & $1,6 \pm 0,7$ \\
\hline & $\mathrm{BY}_{\text {alt }}$ & & & & & $1,2 \pm 0,3$ & $0,7 \pm 0,3$ & $1,0 \pm 0,1$ & $1,3 \pm 0,5$ \\
\hline & $\mathrm{BY}_{\text {ort }}$ & & & & & $0,67 \pm 0,2$ & $0,83 \pm 0,4$ & $1,22 \pm 0,3$ & $1,47 \pm 0,6$ \\
\hline & Ort. & $0,76 \pm 0,6$ & $1,26 \pm 0,8$ & $0,86 \pm 0,7$ & $0,91 \pm 0,8$ & $0,79 \pm 0,7$ & $1,04 \pm 0,7$ & $2,06 \pm 1,7$ & $2,81 \pm 2,1$ \\
\hline
\end{tabular}

Tablo 8b. Örnekleme dönemlerindeki ortalama $\beta$-D değerleri

Table 8 b. Mean soil $\beta$-D glucosidase levels within the sampling period

\begin{tabular}{|c|c|c|c|c|c|c|c|c|c|}
\hline \multirow{2}{*}{$\begin{array}{c}\text { Toprak } \\
\text { özellikleri }\end{array}$} & \multirow[b]{2}{*}{ Uyg. } & \multicolumn{2}{|c|}{ A12 } & \multicolumn{2}{|c|}{ A24 } & \multicolumn{2}{|c|}{ A36 } & \multicolumn{2}{|c|}{ Toplam ortalama } \\
\hline & & M & Çk & M & Çk & M & Çk & M & Çk \\
\hline \multirow{10}{*}{$\begin{array}{l}\beta \text {-D Gliko- } \\
\text { sidaz } \\
\text { mg pNP h-1 } \\
\text { g-1 }\end{array}$} & $\mathrm{K}_{\text {üst }}$ & $2,1 \pm 0,8$ & $3,9 \pm 1,3$ & $1,5 \pm 0,5$ & $1,3 \pm 0,1$ & $0,5 \pm 0,2$ & $0,4 \pm 0,3$ & $1,2 \pm 0,7$ & $2,4 \pm 2,0$ \\
\hline & $\mathrm{K}_{\text {alt }}$ & $3,1 \pm 1,4$ & $2,7 \pm 0,9$ & $0,3 \pm 0,1$ & $0,7 \pm 0,3$ & $0,1 \pm 0,0$ & $0,2 \pm 0,1$ & $3,0 \pm 2,5$ & $1,3 \pm 1,3$ \\
\hline & $\mathrm{K}_{\text {ort }}$ & $4,99 \pm 2,3$ & $3,31 \pm 1,2$ & $0,90 \pm 0,7$ & $1,01 \pm 0,4$ & $0,30 \pm 0,2$ & $0,26 \pm 0,2$ & $2,10 \pm 2,1$ & $1,86 \pm 1,8$ \\
\hline & $\mathrm{EY}_{\text {ust }}$ & $0,5 \pm 0,2$ & $2,4 \pm 1,2$ & $1,3 \pm 1,2$ & $1,0 \pm 1,4$ & $0,3 \pm 0,1$ & $0,1 \pm 0,1$ & $0,7 \pm 0,6$ & $1,5 \pm 1,3$ \\
\hline & $\mathrm{EY}_{\text {alt }}^{\text {ust }}$ & $0,5 \pm 0,5$ & $1,7 \pm 1,2$ & $1,6 \pm 1,3$ & $0,8 \pm 1,3$ & $0,2 \pm 0,1$ & $0,1 \pm 0,1$ & $0,8 \pm 0,7$ & $1,0 \pm 1,2$ \\
\hline & $\mathrm{EY}_{\text {ort }}$ & $0,58 \pm 0,5$ & $2,06 \pm 1,2$ & $1,48 \pm 1,2$ & $0,87 \pm 1,3$ & $0,29 \pm 0,1$ & $0,10 \pm 0,1$ & $0,74 \pm 0,7$ & $1,23 \pm 1,3$ \\
\hline & $\mathrm{BY}_{\text {ust }}$ & $0,8 \pm 0,2$ & $1,3 \pm 0,8$ & $2,0 \pm 1,3$ & $1,0 \pm 1,0$ & $0,3 \pm 0,1$ & $0,1 \pm 0,1$ & $1,0 \pm 1,0$ & $1,0 \pm 0,8$ \\
\hline & $\mathrm{BY}_{\text {alt }}$ & $0,5 \pm 0,4$ & $1,6 \pm 1,1$ & $2,0 \pm 1,3$ & $0,4 \pm 0,3$ & $0,2 \pm 0,1$ & $0,1 \pm 0,1$ & $1,0 \pm 0,8$ & $0,8 \pm 0,8$ \\
\hline & $\mathrm{BY}_{\text {ort }}$ & $0,74 \pm 0,4$ & $1,48 \pm 0,9$ & $2,01 \pm 1,2$ & $0,67 \pm 0,8$ & $0,24 \pm 0,1$ & $0,10 \pm 0,1$ & $0,99 \pm 0,9$ & $0,91 \pm 0,8$ \\
\hline & Ort. & $1,74 \pm 2,2$ & $2,18 \pm 1,3$ & $1,51 \pm 1,1$ & $0,84 \pm 0,9$ & $0,27 \pm 0,1$ & $0,14 \pm 0,2$ & $1,14 \pm 1,3$ & $1,31 \pm 1,4$ \\
\hline
\end{tabular}


yüksek asit fosfataz aktivitesi yangın-uygulama açısından en yüksek seviyesine BY'de (1,29 mg pNP $\left.\mathrm{h}^{-1} \mathrm{~g}^{-1}\right)$ ulaşmış, onu K (0,85 mg pNP $\left.\mathrm{h}^{-1} \mathrm{~g}^{1}\right)$ takip etmiştir (Tablo 9a, b). Karaçam topraklarında dönem, yangın ve dönem*yangın interaksiyonunun önemli olduğu belirlenmiştir. Karaçamda asit fosfataz aktivitesi en yüksek seviyesine A36'da çıkmış en düşük seviyesi ise A1 ve A3'te tespit edilmiştir. Meşede de yine en yüksek seviyesi A36'da ve en düşük seviyesi Al'de tespit edilmiştir (Tablo 9a, b). Asit fosfataz aktivitesinin tüm dönemler ortalamasına bakıldığında yangın sahalarında daha yüksek olduğu bulunmuş, ancak her dönem ayrı ayrı incelendiğinde yaz dönemi dışındaki bütün dönemlerde yanan sahalarda enzim aktivitesinin aslında daha düşük olduğu görülmüştür. Yanan sahalar ile kontrol sahaları arasında yanan sahalar lehine görünen bu farkın sadece A9'da yanan sahalardaki yüksek aktivite değerlerinden kaynaklandığ 1 anlaşılmıştır. Gruplar arasında karaçamda alt toprakta fark bulunmuş EY sahalarının hem K hem BY sahalarına benzer olduğu, $\mathrm{K}$ ve BY sahalarının ise birbirinden farklı olduğu tespit edilmiştir.
Örnekleme dönemi toprağın asit fosfataz aktivitesi üzerinde önemli ölçüde etkili bulunmuştur. Yangından sonraki ilk iki döneme bakıldığında aslında yanginla beraber A1'de asit fosfataz aktivitesinin azaldığ 1 , A3'te kontrol ve yangın sahalarının aynı seviyede olduğu, A6'da K sahalarında daha yüksek asit fosfataz aktivitesinin bulunduğu görülmüştür. A9'da (Eylül) ise yangın sahalarında büyük oranda artış gösteren $\mathrm{K}$ sahalarından daha yüksek asit fosfataz seviyeleri belirlenmiştir. A12'de tekrar düşerek K sahaları lehine gelişen aktivite A36'da tüm sahalarda zirve yapmıştır.

Toprak derinliğinin her iki türde de asit fosfataz aktivitesi üzerine önemli düzeyde etkili olmad1$\breve{g}_{1}$ belirlenmiştir $(\mathrm{P}>0,05)$. EY ve BY sahalarının aynı grupta yer aldığı meşede kontrol sahalarından önemli düzeyde farklı olmadığı ancak karaçam alt topraklarında BY sahası ile K sahasının önemli düzeyde farklı bulunduğu tespit edilmiştir.

Ağaç türleri arasındaki farkın $\mathrm{P}=0,020$ önem düzeyinde olduğu belirlenmiş, asit fosfataz aktivitesi or-

Tablo 9a. Örnekleme dönemlerindeki ortalama Asit fosfataz değerleri

Table 9a. Mean soil acid phosphatase levels within the sampling period

\begin{tabular}{|c|c|c|c|c|c|c|c|c|c|}
\hline \multirow{2}{*}{$\begin{array}{c}\text { Toprak } \\
\text { özellikleri }\end{array}$} & \multirow[b]{2}{*}{ Uyg. } & \multicolumn{2}{|c|}{$\mathrm{A} 1$} & \multicolumn{2}{|c|}{$\mathrm{A} 3$} & \multicolumn{2}{|c|}{ A6 } & \multicolumn{2}{|c|}{ A9 } \\
\hline & & M & Çk & $\mathrm{M}$ & Çk & M & Çk & $\mathrm{M}$ & Çk \\
\hline \multirow{10}{*}{$\begin{array}{c}\text { Asit fosfa- } \\
\text { taz } \\
\mathrm{mg} \mathrm{pNP}^{-1} \mathrm{~h}^{-1}\end{array}$} & $\mathrm{~K}_{\text {üst }}$ & $0,3 \pm 0,0$ & $0,2 \pm 0,0$ & $0,3 \pm 0,0$ & $0,2 \pm 0,0$ & $0,4 \pm 0,1$ & $0,4 \pm 0,0$ & $0,1 \pm 0,0$ & $0,0 \pm 0,0$ \\
\hline & $\mathrm{K}_{\mathrm{alt}}$ & $0,3 \pm 0,0$ & $0,2 \pm 0,0$ & $0,2 \pm 0,0$ & $0,2 \pm 0,0$ & $0,4 \pm 0,1$ & $0,4 \pm 0,1$ & $0,2 \pm 0,1$ & $0,0 \pm 0,0$ \\
\hline & $\mathrm{K}_{\mathrm{ort}}$ & $0,30 \pm 0,0$ & $0,18 \pm 0,0$ & $0,25 \pm 0,0$ & $0,17 \pm 0,0$ & $0,39 \pm 0,1$ & $0,38 \pm 0,1$ & $0,11 \pm 0,1$ & $0,04 \pm 0,0$ \\
\hline & $\mathrm{EY}_{\text {uist }}$ & $0,2 \pm 0,0$ & $0,2 \pm 0,0$ & $0,3 \pm 0,0$ & $0,2 \pm 0,0$ & $0,2 \pm 0,1$ & $0,3 \pm 0,1$ & $0,9 \pm 0,8$ & $1,0 \pm 0,6$ \\
\hline & $\mathrm{EY}_{\text {alt }}$ & $0,2 \pm 0,0$ & $0,2 \pm 0,0$ & $0,3 \pm 0,0$ & $0,2 \pm 0,0$ & $0,2 \pm 0,1$ & $0,2 \pm 0,1$ & $1,4 \pm 1,2$ & $0,9 \pm 0,4$ \\
\hline & $\mathrm{EY}_{\text {ort }}$ & $0,22 \pm 0,0$ & $0,17 \pm 0,0$ & $0,26 \pm 0,0$ & $0,18 \pm 0,0$ & $0,21 \pm 0,1$ & $0,27 \pm 0,1$ & $1,14 \pm 1,0$ & $0,98 \pm 0,5$ \\
\hline & $\mathrm{BY}_{\text {üst }}$ & & & & & $0,2 \pm 0,1$ & $0,3 \pm 0,1$ & $1,5 \pm 1,1$ & $0,7 \pm 0,4$ \\
\hline & $\mathrm{BY}_{\text {alt }}$ & & & & & $0,2 \pm 0,1$ & $0,3 \pm 0,1$ & $1,3 \pm 0,9$ & $0,8 \pm 0,4$ \\
\hline & $\mathrm{BY}_{\text {ort }}$ & & & & & $0,18 \pm 0,1$ & $0,31 \pm 0,1$ & $1,40 \pm 0,9$ & $0,77 \pm 0,4$ \\
\hline & Ort. & $0,24 \pm 0,0$ & $0,18 \pm 0,0$ & $0,26 \pm 0,0$ & $0,18 \pm 0,0$ & $0,24 \pm 0,1$ & $0,31 \pm 0,1$ & $0,97 \pm 1,0$ & $0,68 \pm 0,5$ \\
\hline
\end{tabular}

Tablo 9b. Örnekleme dönemlerindeki ortalama Asit fosfataz değerleri

Table 9b. Mean soil acid phosphatase levels within the sampling period

\begin{tabular}{|c|c|c|c|c|c|c|c|c|c|}
\hline \multirow{2}{*}{$\begin{array}{c}\text { Toprak } \\
\text { özellikleri }\end{array}$} & \multirow[b]{2}{*}{ Uyg. } & \multicolumn{2}{|c|}{ A12 } & \multicolumn{2}{|c|}{ A24 } & \multicolumn{2}{|c|}{ A36 } & \multicolumn{2}{|c|}{ Toplam ortalama } \\
\hline & & M & Çk & M & Çk & M & Çk & M & Çk \\
\hline \multirow{10}{*}{$\begin{array}{c}\text { Asit fosfa- } \\
\text { taz } \\
\mathrm{mg} \mathrm{pNP} \\
\mathrm{h}^{-1} \mathrm{~g}^{-1}\end{array}$} & $\mathrm{~K}_{\text {ust }}$ & $0,3 \pm 0,1$ & $0,3 \pm 0,0$ & $0,3 \pm 0,1$ & $0,3 \pm 0,0$ & $4,3 \pm 0,7$ & $3,6 \pm 0,4$ & $0,9 \pm 1,5$ & $0,7 \pm 1,2$ \\
\hline & $\mathrm{K}_{\text {alt }}$ & $0,2 \pm 0,0$ & $0,2 \pm 0,1$ & $0,2 \pm 0,0$ & $0,2 \pm 0,1$ & $4,4 \pm 0,6$ & $4,5 \pm 0,3$ & $0,8 \pm 1,5$ & $0,8 \pm 1,5$ \\
\hline & $\mathrm{K}_{\text {ort }}$ & $0,27 \pm 0,1$ & $0,25 \pm 0,1$ & $0,27 \pm 0,1$ & $0,25 \pm 0,1$ & $4,37 \pm 0,1$ & $4,05 \pm 0,6$ & $0,85 \pm 1,5$ & $0,76 \pm 1,4$ \\
\hline & $\mathrm{EY}_{\text {üst }}$ & $0,2 \pm 0,1$ & $0,3 \pm 0,1$ & $0,2 \pm 0,1$ & $0,3 \pm 0,1$ & $4,3 \pm 0,2$ & $4,8 \pm 0,4$ & $0,8 \pm 1,3$ & $0,9 \pm 1,5$ \\
\hline & $\mathrm{EY}_{\text {alt }}$ & $0,3 \pm 0,1$ & $0,2 \pm 0,0$ & $0,3 \pm 0,1$ & $0,2 \pm 0,0$ & $3,9 \pm 0,1$ & $3,7 \pm 0,3$ & $0,8 \pm 1,3$ & $0,7 \pm 1,2$ \\
\hline & $\mathrm{EY}_{\text {ort }}$ & $0,25 \pm 0,1$ & $0,26 \pm 0,1$ & $0,25 \pm 0,1$ & $0,26 \pm 0,1$ & $4,11 \pm 0,3$ & $4,29 \pm 0,7$ & $0,79 \pm 1,3$ & $0,78 \pm 1,3$ \\
\hline & $\mathrm{BY}_{\text {üst }}^{\text {ort }}$ & $0,4 \pm 0,1$ & $0,3 \pm 0,1$ & $0,4 \pm 0,1$ & $0,3 \pm 0,1$ & $4,0 \pm 0,4$ & $4,3 \pm 0,7$ & $1,3 \pm 1,5$ & $1,2 \pm 1,6$ \\
\hline & $\mathrm{BY}_{\text {alt }}$ & $0,3 \pm 0,2$ & $0,2 \pm 0,0$ & $0,3 \pm 0,2$ & $0,2 \pm 0,0$ & $4,2 \pm 0,2$ & $3,5 \pm 0,9$ & $1,3 \pm 1,6$ & $1,0 \pm 1,4$ \\
\hline & $\mathrm{BY}_{\text {ort }}$ & $0,38 \pm 0,1$ & $0,27 \pm 0,1$ & $0,38 \pm 0,2$ & $0,27 \pm 0,1$ & $4,12 \pm 0,3$ & $3,90 \pm 0,9$ & $1,29 \pm 1,6$ & $1,11 \pm 1,5$ \\
\hline & Ort. & $0,30 \pm 0,1$ & $0,26 \pm 0,1$ & $0,30 \pm 0,1$ & $0,26 \pm 0,1$ & $4,18 \pm 0,4$ & $4,10 \pm 0,7$ & $0,93 \pm 1,4$ & $0,85 \pm 1,4$ \\
\hline
\end{tabular}


talamalarının meşede yüksek olduğu görülmüştür.

Meşe topraklarında EY ve BY sahalarında üreaz aktivitesinin kontrol sahalarına göre önemsiz düzeyde düşük olduğu anlaşılmıştır.
Üreaz aktivitesi üzerine dönemin etkisi hem meşe $\mathrm{P}<0,01$ hem karaçam $(\mathrm{P}<0,05)$ topraklarında önemli düzeyde bulunmuştur. Hem meşe hem karaçam topraklarında dönem açısından üreaz en yüksek seviyesine A36'da ulaşmıştır (Tablo 10a, b). Üç grup arasında en yüksek üreaz düzeyi BY'de tespit edilmiştir. Tüm dönemlere bakıldığında bu

Tablo 10a. Örnekleme dönemlerindeki ortalama Üreaz değerleri

Table 10a. Mean soil Urease levels within the sampling period

\begin{tabular}{|c|c|c|c|c|c|c|c|c|c|}
\hline \multirow{2}{*}{$\begin{array}{c}\text { Toprak } \\
\text { özellikleri }\end{array}$} & \multirow[b]{2}{*}{ Uyg. } & \multicolumn{2}{|c|}{$\mathrm{A} 1$} & \multicolumn{2}{|c|}{$\mathrm{A} 3$} & \multicolumn{2}{|c|}{ A6 } & \multicolumn{2}{|c|}{ A9 } \\
\hline & & $\mathrm{M}$ & Çk & $\mathrm{M}$ & Çk & $\mathrm{M}$ & Çk & $\mathrm{M}$ & Çk \\
\hline \multirow{10}{*}{$\begin{array}{c}\text { Üreaz } \\
\text { N g-1 to- } \\
\text { prak }\end{array}$} & $\mathrm{K}_{\text {ust }}$ & $0,1 \pm 0,0$ & $0,1 \pm 0,0$ & $0,1 \pm 0,0$ & $0,1 \pm 0,0$ & $0,1 \pm 0,0$ & $0,1 \pm 0,0$ & $0,1 \pm 0,0$ & $0,1 \pm 0,0$ \\
\hline & $\mathrm{K}_{\mathrm{alt}}$ & $0,1 \pm 0,0$ & $0,1 \pm 0,0$ & $0,1 \pm 0,0$ & $0,1 \pm 0,0$ & $0,1 \pm 0,0$ & $0,1 \pm 0,0$ & $0,1 \pm 0,0$ & $0,1 \pm 0,0$ \\
\hline & $\mathrm{K}_{\text {ort }}$ & $0,06 \pm 0,0$ & $0,05 \pm 0,0$ & $0,06 \pm 0,0$ & $0,06 \pm 0,0$ & $0,06 \pm 0,0$ & $0,06 \pm 0,0$ & $0,05 \pm 0,0$ & $0,05 \pm 0,0$ \\
\hline & $\mathrm{EY}_{\text {ust }}$ & $0,1 \pm 0,0$ & $0,1 \pm 0,0$ & $0,1 \pm 0,0$ & $0,1 \pm 0,0$ & $0,1 \pm 0,0$ & $0,1 \pm 0,0$ & $0,1 \pm 0,0$ & $0,1 \pm 0,0$ \\
\hline & $\mathrm{EY}_{\text {alt }}$ & $0,1 \pm 0,0$ & $0,1 \pm 0,0$ & $0,1 \pm 0,0$ & $0,1 \pm 0,0$ & $0,1 \pm 0,0$ & $0,1 \pm 0,0$ & $0,1 \pm 0,0$ & $0,1 \pm 0,0$ \\
\hline & $\mathrm{EY}_{\text {ort }}$ & $0,05 \pm 0,0$ & $0,05 \pm 0,0$ & $0,06 \pm 0,0$ & $0,06 \pm 0,0$ & $0,05 \pm 0,0$ & $0,06 \pm 0,0$ & $0,05 \pm 0,0$ & $0,05 \pm 0,0$ \\
\hline & $\mathrm{BY}_{\text {üst }}$ & & & & & $0,1 \pm 0,0$ & $0,1 \pm 0,0$ & $0,1 \pm 0,0$ & $0,1 \pm 0,0$ \\
\hline & $\mathrm{BY}_{\text {alt }}$ & & & & & $0,1 \pm 0,0$ & $0,1 \pm 0,0$ & $0,1 \pm 0,0$ & $0,1 \pm 0,0$ \\
\hline & $\mathrm{BY}_{\text {ort }}$ & & & & & $0,05 \pm 0,0$ & $0,06 \pm 0,0$ & $0,05 \pm 0,0$ & $0,05 \pm 0,0$ \\
\hline & Ort. & $0,05 \pm 0,0$ & $0,05 \pm 0,0$ & $0,06 \pm 0,0$ & $0,06 \pm 0,0$ & $0,05 \pm 0,0$ & $0,06 \pm 0,0$ & $0,05 \pm 0,0$ & $0,05 \pm 0,0$ \\
\hline
\end{tabular}

Tablo 10b. Örnekleme dönemlerindeki ortalama Üreaz değerleri

Table 10b. Mean soil Urease levels within the sampling period

\begin{tabular}{|c|c|c|c|c|c|c|c|c|c|}
\hline \multirow{2}{*}{$\begin{array}{c}\text { Toprak } \\
\text { özellikleri }\end{array}$} & \multirow[b]{2}{*}{ Uyg. } & \multicolumn{2}{|c|}{$\mathrm{A} 12$} & \multicolumn{2}{|c|}{ A24 } & \multicolumn{2}{|c|}{ A36 } & \multicolumn{2}{|c|}{ Toplam ortalama } \\
\hline & & $M$ & Çk & $M$ & Çk & $\mathrm{M}$ & Çk & $M$ & Çk \\
\hline \multirow{10}{*}{$\begin{array}{l}\text { Üreaz } \\
\text { N g-1 to- } \\
\text { prak }\end{array}$} & $\mathrm{K}_{\text {uist }}$ & $0,1 \pm 0,0$ & $0,1 \pm 0,0$ & $0,0 \pm 0,0$ & $0,2 \pm 0,1$ & $1,6 \pm 0,6$ & $0,2 \pm 0,1$ & $0,3 \pm 0,6$ & $0,1 \pm 0,1$ \\
\hline & $\mathrm{K}_{\text {alt }}$ & $0,1 \pm 0,0$ & $0,1 \pm 0,0$ & $1,6 \pm 2,7$ & $0,0 \pm 0,0$ & $0,4 \pm 0,2$ & $0,4 \pm 0,1$ & $0,3 \pm 1,0$ & $0,1 \pm 0,1$ \\
\hline & $\mathrm{K}_{\text {ort }}$ & $0,05 \pm 0,0$ & $0,05 \pm 0,0$ & $0,80 \pm 1,9$ & $0,11 \pm 0,1$ & $0,97 \pm 0,8$ & $0,31 \pm 0,1$ & $0,29 \pm 0,8$ & $0,10 \pm 0,11$ \\
\hline & $\mathrm{EY}_{\text {ust }}$ & $0,1 \pm 0,0$ & $0,1 \pm 0,0$ & $0,3 \pm 0,4$ & $0,2 \pm 0,2$ & $1,7 \pm 1,2$ & $0,2 \pm 0,1$ & $0,3 \pm 0,7$ & $0,1 \pm 0,1$ \\
\hline & $\mathrm{EY}_{\text {alt }}$ & $0,1 \pm 0,0$ & $0,1 \pm 0,0$ & $0,0 \pm 0,0$ & $0,1 \pm 0,1$ & $0,7 \pm 0,2$ & $0,1 \pm 0,0$ & $0,1 \pm 0,2$ & $0,1 \pm 0,1$ \\
\hline & $\mathrm{EY}_{\mathrm{ort}}^{\text {ait }}$ & $0,05 \pm 0,0$ & $0,05 \pm 0,0$ & $0,19 \pm 0,3$ & $0,14 \pm 0,1$ & $1,22 \pm 1,0$ & $0,18 \pm 0,1$ & $0,21 \pm 0,5$ & $0,08 \pm 0,07$ \\
\hline & $\mathrm{BY}_{\text {üst }}$ & $0,1 \pm 0,0$ & $0,1 \pm 0,0$ & $0,5 \pm 0,8$ & $0,0 \pm 0,0$ & $2,2 \pm 2,0$ & $0,9 \pm 0,3$ & $0,6 \pm 1,2$ & $0,2 \pm 0,4$ \\
\hline & $\mathrm{BY}_{\text {alt }}$ & $0,1 \pm 0,0$ & $0,1 \pm 0,0$ & $0,5 \pm 0,8$ & $0,1 \pm 0,1$ & $0,6 \pm 0,2$ & $0,6 \pm 0,2$ & $0,2 \pm 0,4$ & $0,2 \pm 0,2$ \\
\hline & $\mathrm{BY}_{\text {ort }}$ & $0,05 \pm 0,0$ & $0,05 \pm 0,0$ & $0,47 \pm 0,7$ & $0,06 \pm 0,1$ & $1,40 \pm 1,6$ & $0,76 \pm 0,3$ & $0,41 \pm 0,9$ & $0,20 \pm 0,31$ \\
\hline & Ort. & $0,05 \pm 0,0$ & $0,05 \pm 0,0$ & $0,44 \pm 1,0$ & $0,11 \pm 0,1$ & $1,22 \pm 1,1$ & $0,40 \pm 0,3$ & $0,27 \pm 0,7$ & $0,11 \pm 0,17$ \\
\hline
\end{tabular}

Tablo 11a. Örnekleme dönemlerindeki ortalama Cmic/Corg değerleri

Table 11a. Mean soil Cmic/Corg levels within the sampling period

\begin{tabular}{|c|c|c|c|c|c|c|c|c|c|}
\hline \multirow{2}{*}{$\begin{array}{c}\text { Toprak } \\
\text { özellikleri }\end{array}$} & \multirow[b]{2}{*}{ Uyg. } & \multicolumn{2}{|c|}{ A1 } & \multicolumn{2}{|c|}{ A3 } & \multicolumn{2}{|c|}{ A6 } & \multicolumn{2}{|c|}{ A9 } \\
\hline & & $\mathrm{M}$ & Çk & $\mathrm{M}$ & Çk & $\mathrm{M}$ & Çk & $\mathrm{M}$ & Çk \\
\hline \multirow{10}{*}{$\begin{array}{c}\text { Cmic/ Corg } \\
\%\end{array}$} & $\mathrm{~K}_{\text {üst }}$ & $5,1 \pm 0,5$ & $3,7 \pm 1,7$ & $1,5 \pm 0,3$ & $4,0 \pm 2,0$ & $16,7 \pm 6,0$ & $6,2 \pm 3,0$ & $6,7 \pm 6,6$ & $11,9 \pm 4,0$ \\
\hline & $\mathrm{K}_{\mathrm{alt}}$ & $8,6 \pm 2,9$ & $2,5 \pm 1,4$ & $20,5 \pm 6,1$ & $5,8 \pm 7,3$ & $12,4 \pm 6,2$ & $8,7 \pm 5,2$ & $5,5 \pm 7,1$ & $7,5 \pm 2,3$ \\
\hline & $\mathrm{K}_{\mathrm{ort}}$ & $6,9 \pm 2,8$ & $3,1 \pm 1,6$ & $11,0 \pm 11,1$ & $4,9 \pm 4,9$ & $14,5 \pm 5,9$ & $7,5 \pm 4,0$ & $6,1 \pm 6,2$ & $9,7 \pm 3,8$ \\
\hline & $E Y_{\text {üst }}$ & $3,7 \pm 2,4$ & $4,6 \pm 1,6$ & $3,3 \pm 0,8$ & $8,0 \pm 1,9$ & $11,2 \pm 4,1$ & $12,0 \pm 1,9$ & $13,5 \pm 4,8$ & $14,9 \pm 9,0$ \\
\hline & $\mathrm{EY}_{\mathrm{alt}}$ & $11,0 \pm 4,2$ & $4,2 \pm 1,3$ & $10,3 \pm 6,3$ & $7,4 \pm 2,7$ & $20,3 \pm 15,3$ & $15,4 \pm 3,0$ & $19,0 \pm 11,6$ & $31,3 \pm 38,5$ \\
\hline & $\mathrm{EY}_{\text {ort }}$ & $7,3 \pm 5,1$ & $4,4 \pm 1,4$ & $6,8 \pm 5,6$ & $7,7 \pm 2,3$ & $15,8 \pm 11,6$ & $1,4 \pm 3,0$ & $16,3 \pm 8,9$ & $23,1 \pm 28$ \\
\hline & $\mathrm{BY}_{\text {üst }}$ & & & & & $10,7 \pm 3,6$ & $12,0 \pm 1,7$ & $15,9 \pm 7,7$ & $17,3 \pm 17,1$ \\
\hline & $\mathrm{BY}_{\text {alt }}$ & & & & & $20,0 \pm 2,7$ & $13,4 \pm 4,2$ & $17,2 \pm 3,3$ & $33,5 \pm 21,3$ \\
\hline & $\mathrm{BY}_{\mathrm{ort}}$ & & & & & $15,4 \pm 5,8$ & $1,3 \pm 3,0$ & $16,5 \pm 5,6$ & $25,4 \pm 20$ \\
\hline & Ort. & $7,2 \pm 4,5$ & $4,1 \pm 1,5$ & $7,9 \pm 7,3$ & $7,0 \pm 3,3$ & $15,3 \pm 8,4$ & $1,2 \pm 4,1$ & $13,8 \pm 8,3$ & $20,5 \pm 22$ \\
\hline
\end{tabular}


Tablo 11b. Örnekleme dönemlerindeki ortalama Cmic/Corg değerleri

Table 11b. Mean soil Cmic/Corg levels within the sampling period

\begin{tabular}{ccrrrrrrrr}
\hline \multirow{2}{*}{$\begin{array}{c}\text { Toprak } \\
\text { özellikleri }\end{array}$} & Uyg. & \multicolumn{2}{c}{$\mathrm{M}$} & \multicolumn{1}{c}{ Çk } & \multicolumn{1}{c}{$\mathrm{M}$} & \multicolumn{1}{c}{ Çk } & \multicolumn{1}{c}{ M } & \multicolumn{1}{c}{ Çk } & \multicolumn{3}{c}{ M } & Çk \\
\cline { 3 - 9 } & $\mathrm{K}_{\text {usst }}$ & $8,3 \pm 2,2$ & $4,7 \pm 1,2$ & $15,0 \pm 14,6$ & $17,9 \pm 16,7$ & $23,5 \pm 9,3$ & $109 \pm 120$ & $11,0 \pm 9,6$ & $22,5 \pm 53$ \\
& $\mathrm{~K}_{\text {alt }}$ & $6,5 \pm 1,2$ & $10,0 \pm 4,0$ & $17,5 \pm 0,5$ & $17,2 \pm 8,2$ & $70,4 \pm 35,2$ & $119,5 \pm 91$ & $20,2 \pm 25$ & $24,5 \pm 49$ \\
& $\mathrm{~K}_{\text {ort }}$ & $7,4 \pm 1,9$ & $7,4 \pm 3,9$ & $16,3 \pm 9,3$ & $17,6 \pm 11,8$ & $47,0 \pm 21,3$ & $114 \pm 65$ & $15,6 \pm 12,6$ & $23,5 \pm 32$ \\
& $\mathrm{EY}_{\text {ust }}$ & $13,5 \pm 3,5$ & $5,0 \pm 4,2$ & $19,7 \pm 12,5$ & $24,5 \pm 8,2$ & $18,6 \pm 5,3$ & $246 \pm 177$ & $10,4 \pm 8,1$ & $37,8 \pm 94,3$ \\
Cmic/ & $\mathrm{EY}_{\text {alt }}$ & $13,2 \pm 1,6$ & $6,5 \pm 2,0$ & $13,2 \pm 5,2$ & $26,0 \pm 21,9$ & $167 \pm 217$ & $186 \pm 113$ & $31,6 \pm 83,9$ & $33,3 \pm 68,2$ \\
Corg & $\mathrm{EY}_{\text {ort }}$ & $13,4 \pm 2,6$ & $5,7 \pm 3,2$ & $16,5 \pm 9,7$ & $25,3 \pm 15,6$ & $92,3 \pm 13,9$ & $217 \pm 11$ & $21,0 \pm 10,2$ & $35,6 \pm 63$ \\
& $\mathrm{BY}_{\text {ust }}$ & $13,4 \pm 7,2$ & $10,0 \pm 5,2$ & $19,5 \pm 8,0$ & $17,7 \pm 2,8$ & $18,1 \pm 5,1$ & $268,4 \pm 66$ & $15,5 \pm 6,7$ & $65,1 \pm 108$ \\
& $\mathrm{BY}_{\text {alt }}$ & $10,0 \pm 5,2$ & $6,4 \pm 5,2$ & $2,5 \pm 1,0$ & $30,0 \pm 3,3$ & $90,7 \pm 50$ & $303 \pm 147$ & $28,1 \pm 38$ & $77,2 \pm 130$ \\
& $\mathrm{BY}_{\text {ort }}$ & $11,7 \pm 6,1$ & $8,2 \pm 5,2$ & $11,0 \pm 10,5$ & $23,9 \pm 7,2$ & $54,4 \pm 12,7$ & $286 \pm 48$ & $21,8 \pm 63,5$ & $71,1 \pm 82$ \\
& Ort. & $11,3 \pm 4,5$ & $7,0 \pm 4,1$ & $14,6 \pm 9,8$ & $22,9 \pm 12,3$ & $68,6 \pm 78,4$ & $214 \pm 98$ & $19,8 \pm 32,9$ & $41,0 \pm 64$ \\
\hline
\end{tabular}

durumun A36'daki K, EY ve BY farkından kaynaklandığı anlaşılmaktadır.

Türün üreaz üzerinde istatistiksel olarak önemli düzeyde etkili olmadığı tespit edilmiştir $(\mathrm{P}>0,05)$.

Cmic/Corg oranı üzerine yangın-boşaltma ve dönem meşe topraklarında etkili bulunurken, karaçam üzerinde yangın-boşaltma, dönem ve derinliğin etkili olduğu anlaşılmıştır. Sahayı boşaltmanın her iki tür topraklarında $\mathrm{Cmic} / \mathrm{Corg}$ oranını artırdığ 1 görülmüştür.

Örnekleme dönemi tüm örneklerde Cmic/Corg oranını önemli düzeyde etkilemiştir, bu oranın en yüksek gözlendiği dönemler meşede ve karaçamda A36'dir (Tablo 11a, b).

Toprak derinliği Cmic/Corg oranını önemli düzeyde etkilemiştir $(\mathrm{P}<0,01)$. Alt derinlik kademesinde $\mathrm{Cmic} /$ Corg oranının daha yüksek olduğu belirlenmiş; türlerin sadece alt toprakta farklı etkisinin olduğu görülmüştür $(\mathrm{P}=0,001)$.

\section{Tartışma ve Sonuc}

Araştırmamızda orman yangınının ve dönemin etkisi göz önüne alındığında sonuçların farklı türlerde ve farklı derinliklerde genellikle aynı yönde değişim gösterdiği tespit edilmiştir. Üçüncü toprak örneklemesinden itibaren yanan ağaç enkazının kaldırılmış veya bırakılmış olmasının etkisine bakıldığında EY ve BY sahalarının gruplandırmalarda büyük çoğunlukla aynı grupta yer aldığ görülmüştür.

Orman yangınının etkisi $\mathrm{pH}, \mathrm{CaCO}_{3}, \mathrm{Ca}, \mathrm{P}_{2} \mathrm{O}_{5}, \mathrm{OM}$ (karaçam topraklarında), $\beta$-D glikosidaz ve asit fosfataz üzerinde önemli düzeyde bulunmuştur. Yangınla beraber pH düzeyi artmıştır. Orman yangını, toprak pH'sını iki şekilde artırmaktadır. Birincisi; ölü örtüdeki ve topraktaki ayrışmamış asetik asit gibi organik asitlerin yanarak sistemden uzaklaşmasıdır. İkincisi baz katyonların yangınla birlikte açığa çıkmasıdır ki bu topraktaki H+ iyonunun tüketilmesi ile ilişkilidir (Fisher ve Binkley, 2000).

Araştırma sahamızdan alınan topraklarda orman yangınıyla beraber $\mathrm{CaCO}_{3}$ ve $\mathrm{Ca}$ değerlerinde karaçamda ve meşede önemli düzeyde artış belirlenmiştir. Enkazın kaldırılmasından itibaren her iki türde ve derinlikte bu değişkenler bakımından $\mathrm{K}$ ve yangın saha grupları (EY ve BY sahaları benzer olmakla beraber) birbirinden önemli düzeyde farklı bulunmuştur. Fosfor, potasyum, kalsiyum ve magnezyum gibi bir çok besin elementinin yangınla beraber açığa çıkarak miktarlarının arttığı kaydedilmiştir (Adams ve Boyle, 1980; Khanna ve Raison, 1986; Khanna ve ark., 1994; Tomkins ve ark., 1991; Hernandez ve ark., 1997; Blank ve Zamudio, 1998; Ludwig ve ark., 1998; Simard ve ark., 2001).

Goforth vd. (2005) orman yangınından sonra yangın öncesi karbonat içeriği düşük toprak yüzeyindeki külde toprağa karışmak üzere yüksek miktarda $\mathrm{CaCO}_{3}$ birikimi tespit etmişlerdir. $\mathrm{CaCO}_{3}$ yüzdesindeki değişim $\mathrm{Ca}$ miktarındaki değişimle paralellik göstermektedir. Çam ve meşe odun külünde bol miktarda Ca bulunduğu, küldeki alkalin oksitlerin zaman içinde $\mathrm{CO}_{2}$ ve su buharı ile reaksiyona girerek çözünebilir hidroksit ve karbonatları oluşturduğu ifade edilmiştir (Etiegni ve Campell, 1991; Ulery ve ark., 1993). Yine Goforth ve ark. (2005) ibreli ağaçların yoğun bulunduğu bölümden alınan küllerde daha üniform hâlde oluşan alkalin oksitlerin $\mathrm{CaCO}_{3}$ oluşumu için alınabilir hâlde olduğunu belirtmişlerdir. Diğer taraftan kireç toprağın mineral kısmında bulunur. $\mathrm{CaCO}_{3}$ artış1, ölçümlerin, organik madde içeriği daha fazla olan kontrol sahalarını ve organik madde miktarı yanma ile azalan yangın sahalarını temsilen eşit miktarda toprakta yapılmasına bağlı da olabilir. 
Yarayışlı fosfor düzeyleri her iki türde orman yangınıyla beraber önemli düzeyde artış göstermiştir. Yangına maruz kalmış topraklarda $\mathrm{P}_{2} \mathrm{O}_{5}$ düzeylerinde artış kaydedilmiştir (Kutiel ve Shaviv, 1992; Boydak ve ark., 1996; Esquilin ve ark., 2008; Yıldız ve ark., 2010). pH'daki artış genellikle demir ve alüminyumda bağlı olan fosforu artırır. Yine yanmış toprakta artan mikrobiyal aktivite organik maddede bağlı fosforu açığa çıkarır (Fisher ve Binkley, 2000).

Orman yangınının organik madde (OM) üzerindeki etkisi karaçamda önemli bulunmuştur. Yanmış topraklarda OM miktarının daha düşük olduğu görülmüştür (Boydak ve ark., 1996). Bünyelerindeki yoğun reçineden ötürü karaçam ibrelerindeki şiddetli yanmaya bağlı olarak organik maddede kayıp oluşmuş olabilir.

Etkisi önemli bulunmamakla birlikte toplam azotta da orman yangınıyla beraber artış tespit edilmiştir. Yangınla 1sınan toprakta humus mineralizasyonu ve buna bağlı olarak nitrifikasyon artmaktadır (Çepel, 1975). Toros sediri deneme alanlarında, toprak örneklerine ait analiz sonuçlarına göre toplam N miktarı yakma işleminden önceki değerlerden $(\% 0,63)$, yakma işleminden hemen sonra daha yüksek $(\% 0,92)$ bulunmuş, bir yıl sonra yaklaşık yakma öncesi değere $(\% 0,61)$ yeniden ulaşmıştır (Boydak ve ark., 1996).

Araştırma sonuçlarımız değerlendirildiğinde orman yangınının genel olarak $\beta$-D glikosidaz aktivitesini azalttığ 1 belirlenmiştir. $\beta$-D glikosidaz enzimi $\mathrm{pH}$ değişimlerine ve toprak yönetimi uygulamalarına çok hassas, optimum $\mathrm{pH}$ düzeyi 6 , toprağın organik maddeyi dengeleme kapasitesini yansitabilen ve uygulamaların toprak üzerindeki etkilerinin belirlenmesinde kullanılan bir parametredir (Acosta-Martinez ve Tabatabai, 2000). Araştırmamızda yangınla genel olarak bu enzim seviyesindeki azalma pH'nın yükselmesine ve organik maddedeki azalmaya bağlı olabilir.

Tüm mikrobiyal aktivitenin indikatörlerinden biri olan asit fosfataz aktivitesi, yangın sonucunda çoğunlukla azalır (Saa ve ark., 1993; Eivasi ve Bayan, 1996; Boerner ve ark., 2000). Ancak çalışmamızda bu enzim aktivitesinin yanan sahalardan boşaltılmış olanlarda önemli düzeyde arttığı bulunmuştur. Değișen substrat yapısı ve özellikle BY sahalarında artışın yüksek oluşundan yola çıkarak yangın ve boşaltma kesimleri ile açılan toprak yüzeyindeki ısınmanın mikrobiyal etkinlikteki artış üzerinde etkili olduğu anlaşılmaktadır. Nitekim artan mikrobiyal etkinlik sonucu fosfor düzeyinde de artış saptanmıştır. Asit fosfatazın EY sahalarında daha az artışı ise artan fosforun asit fosfatazı engelleyici etkisiyle açıklanabilir. Diğer taraftan BY sahalarındaki yüksek mikrobiyal biyokütle fosfor açısından doygunluğa ulaşamamış ve asit fosfataz etkinliği artarak fosfor artışını desteklemeye devam ediyor olabilir. BY sahalarında Cmic/Corg düzeylerindeki artış da bu görüşümüzü desteklemektedir.

Yanan ağaç enkazının kaldırılması (boşaltma) meşe topraklarında yukarıda irdelenen asit fosfataz ile beraber, $\mathrm{pH}$, üreaz ve $\mathrm{Cmic/Corg}$ bakımından da etkili bulunmuştur. Bu topraklarda yangına ek olarak boşaltmanın yani yanan ağaçların sahadan uzaklaştırılmasının da toprak reaksiyonunu artırdığ 1 tespit edilmiştir. Yapraklı türlerin büyük çoğunluğu asit humus oluşturmazken meşelerin bir çoğunun bu genellemenin dışında kaldığı bildirilmiştir (Kantarcı, 2000). Bu bilgi ışığında araştırma sahamızdan meşe ağacı kalıntılarının uzaklaştırılmasının asit humus oluşumunu da azaltmış olması beklenir ve böylece boşaltılmış sahada asitlik azalmış olabilir.

Üreaz aktivitesi çalışmamızda orman yangınıyla beraber meşe üst topraklarında önemli düzeyde azalmıştır. Hernandez ve ark. (1997), Akdeniz çam ormanında yangının kısa dönemli etkilerini inceledikleri çalışmalarında yangından sonra üreaz enzim aktivitesinin azaldığını bildirmişlerdir. Eucalyptus globulus ve Quercus robur karış1k ormanında yapılan çalışmada da yangının üreaz aktivitesine olumsuz etkisinin gözlendiği bildirilmiştir (Barreiro ve ark., 2015).

Sahayı boşaltmanın her iki tür topraklarında Cmic/ Corg oranını artırdığ1 görülmüştür. Bu oran arttığında topraktaki yarayışlı organik madde konsantrasyonu artmaktadır (Brookes, 1995).

pH (karaçam topraklarında), EC, OM, Cmic/Corg, $\beta$-glikosidaz, asit fosfataz ve üreaz değerleri dönemler arasında önemli düzeyde farklı bulunmuştur. Toprak reaksiyonu, toprağın oluşum ve gelişiminde etkili olan bütün faktörler tarafından etkilenmektedir. İklim, mevsim değişiklikleri ve bitki örtüsü orman topraklarının reaksiyonunu etkileyen en önemli faktörler arasında yer almaktadır (Fitzpatrick, 1986; Foth, 1990; Miller ve Donahue, 1990). Bu konuda yapılan çalışmalara baktığımızda, nemli bölgelerdeki toprakların oldukça asidik topraklara sahip olmaları, bunun nedeninin ise fazla yağışın toprakta bulunan temel katyonları yıkaması $\left(\mathrm{Ca}^{+2}, \mathrm{Mg}^{+2}, \mathrm{~K}^{+}\right.$ve $\left.\mathrm{Na}^{+}\right)$ve geriye değişim komplekslerinde baskın olan $\mathrm{Al}^{+3}$ ve $\mathrm{H}^{+}$iyonlar1nı bırakması olarak açıklanmaktadır (Eriksson ve ark., 1992; Brady ve Weil 1999). Yağışın düşük olduğu yerlerde ise bunun tersi durum meydana gelmektedir. Sonbaharda, yaprak dökümü ile ayrışan örtünün katyonlarının toprağa ulaşmasının ve ve- 
jetasyon faaliyetlerinin yavaşlamasının toprak $\mathrm{pH}$ değerlerini yükselttiği, ilkbaharda ise vejetatif faaliyetin başlamasıyla katyonların topraktan alınmasının, kök ve diğer canlıların solunumu sonucu ortaya çıkan $\mathrm{CO}_{2}$ 'in toprakta zayıf asit olan karbonik asit üretiminin toprak $\mathrm{pH}$ değerlerini düşürdüğü bildirilmektedir (Bergvist ve Folkeson, 1995; Ergene, 1997; Kantarc1, 2000). Bizim çalışmamızda sadece ilkbaharda ilk yıl ölçüm alınmıştır ve sonbahar mevsimini temsil eden A12 ve A36'da pH en yüksek değerlerini almıştır.

Çalışmamıza göre, elektriksel iletkenlik orman yangınıyla birlikte önemli düzeyde olmamakla beraber artmış, ancak bu artış A9'dan itibaren azalmaya başlamıştır. Dönemler ortalamasına bakıldığında ise EC değerlerinin K sahalarında yüksek olduğu görülmüştür. Bu sonuçlara göre yangının önemsiz düzeydeki EC değerlerini yükseltici etkisi, A9 (orman yangınından 10 ay kadar sonra) itibarıla kaybolmaktadır.

Örnekleme dönemi üst topraklarda OM'yi önemli düzeyde etkilemiş, organik maddenin sıcak aylarda bir miktar yükselmekle birlikte dönemler boyunca azaldığı belirlenmiştir.

Cmic/Corg oranında olduğu gibi $\beta$-D glikosidaz enzim aktivitesi dönemden önemli düzeyde etkilenmiş meşede ve karaçamda A9'da en yüksek seviyesinde gözlenmiştir. Selülozun nişastaya ve şekere dönüşümünde görevli üç ya da daha fazla enzimden biri olan $\beta$-D glikosidaz, $\beta$-D glikoprunazın hidrolizini katalizlemektir (Karaca ve ark., 2011) ve karbon döngüsünde rol oynayan bir enzimdir.

$\mathrm{Bu}$ araştırmada asit fosfataz aktivitesi bakımından tüm dönemlerin ortalamaları istatistiksel olarak yanan ve yanmayan sahalarda (karaçam alt toprakları hariç) önemli düzeyde farklı bulunmamıştır. Fakat tüm dönemler ortalaması yangın sahalarında bu enzim aktivitesinin daha yüksek olduğunu göstermiş ve bu yüksek değerin A9 (yaz sonu) değerlerinden kaynaklandığı anlaşılmıştır. Boerner ve ark. (2005), yanmış ve yanmamış sahada asit fosfataz aktivitesini mevsimsel olarak incelemişler ve ortalama $1,57 \mathrm{mmol} / \mathrm{kg}$ toprak/s bulmuşlardır. Yine aynı çalışmada yangından sonra Mayıs ayında yaptıkları ölçümlerde asit fosfataz aktivitesinin yanmış sahalarda yanmamış (kontrol) sahalara göre daha düşük olduğu, sonraki aylarda ise yanmış sahalarda asit fosfataz aktivitesinin artarak kontrol sahalarındaki aktiviteyi aştığı belirlenmiştir. Eylül ayında ise yangın sahaları asit fosfataz aktivitesinin kontrol sahalarına göre çok önemli düzeyde yükseldiği, Kasım'da hem yangın sahasında hem kontrol sahasında aktivitenin bir miktar düşmekle birlikte yangın ve kontrol sahalarında yangın sahası lehine önemli düzeyde yüksek kaldığg kaydedilmiştir.

Aslında her dönem ayrı incelendiğinde yaz dışındaki bütün dönemlerde yanan sahalarda enzim aktivitesi daha düşük, buna karşılık yarayışlı fosfor düzeyleri daha yüksek bulunmuştur. Topraktaki hazırdaki yüksek yarayışlı fosfor düzeyi mikroorganizmaların asit fosfataz enzimi salgılamasına firsat vermediğinden enzim aktivitesinin düşük olması muhtemeldir (Clarholm, 1993). Ancak bu konunun farklı araştırmalarla incelenmesi faydalı olacaktır. Çünkü yarayışlı fosfor düzeyindeki değişim sadece yaz dönemindeki asit fosfataz enzim aktivitesindeki artışı açıklamak için yeterli bulunmamaktadır. Dönemler arası farka bakıldığında son dönemde (A36) asit fosfataz aktivitesinin çok yüksek oranda ve tüm sahalarda arttığı tespit edilmiştir. $\mathrm{Bu}, 2014$ yılı yağış ortalamalarının yörede aynı yönde fazla oluşuna bağlanabilir.

Çalışmamıza dönemler açısından bakıldığında A36'daki yüksek üreaz değerlerinin asit fosfataz enzimindeki gibi o yıl yağış ortalamalarının yüksekliğine bağlı olduğu düşünülmektedir.

Cmic/Corg oranı orman yangınından önemli düzeyde etkilenmezken enkaz ağaçların boşaltılmasindan ve dönemden önemli düzeyde etkilenmiştir. Bu oran, meşede ve karaçamda A36'da en yüksek bulunmuştur.

pH, EC, OM, TN, $\mathrm{CaCO}_{3}, \mathrm{Ca}$ ve $\mathrm{P}_{2} \mathrm{O}_{5}$ meşe ve karaçam topraklarında önemli düzeyde farklı bulunmuştur. Yapraklı türlerden meşelerin pek çoğu ve yaprakları sıkı istiflendiği takdirde kayın dışındaki yapraklı türler asit humus oluşturmamaktadır (Kantarcı, 2000). Buna karşılık, iğne yapraklı türlerden gelen reçineli ve asitli iğne yaprakların da toprak asitliliğini önemli derecede artırdığ 1 bilinmektedir (Barnes ve ark., 1998; Brady ve Weil, 1999; Kantarcı, 2000). Bu çalıșmanın sonuçları da iğne yapraklı karaçam topraklarında asitliğin yüksek olduğunu ve $\mathrm{pH}$ değerlerinin meşe topraklarına göre daha düşük olduğunu göstermektedir.

Türlerin EC değerlerinin önemli düzeyde farklı olması ve bu değerlerin meşede daha yüksek bulunmaS1 pH sonuçlarıyla paralellik göstermektedir. Katyon kullanma istekleri daha fazla olan türlerin ölü örtülerinin ayrışmasıyla toprağa kazandırdıkları katyon miktarları da daha fazladır (Sarıyıldız, 2004).

Meşe altında gelişen topraklarda OM miktarı önemli düzeyde yüksektir. Yapraklı türlerde iğne yapraklı türlere göre ayrışma daha hızlıdır. İğne yaprakların ayrışarak içindeki besin maddelerinden bitkinin faydalanabileceği humuslaşmayı meydana getirebil- 
meleri çok uzun zaman alır (Çepel, 1975).

Toplam azot içeriği bakımından iki tür önemli düzeyde farklı bulunmuş, karaçam türü topraklarında azot içeriği meşeden düşük tespit edilmiştir. Meşe ve çam türleri yaprak $\mathrm{N}$ içeriklerindeki farkl11ık meşe topraklarında bu farkı oluşturmuş olabilir. Nitekim meşe ölü örtüsünde birçok besin elementi yanında $\mathrm{N}$ içeriğinin de yüksek olduğu bildirilmiştir (Woodwell ve ark., 1975; Klemmedson, 1992).

Çam ve meşe odun külünde bol miktarda Ca bulunduğu ve küldeki alkalin oksitlerin zaman içinde $\mathrm{CO}_{2}$ ve su buharı ile reaksiyona girerek çözünebilir hidroksit ve karbonatları oluşturduğu ifade edilmiştir (Etiegni ve Campell, 1991; Ulery ve ark., 1993). Meşe yaprak ve ölü örtüsü N, S, Ca ve Mg gibi besin elementlerince çam türlerine göre daha zengin bulunmuştur (Woodwell ve ark., 1975; Klemmedson, 1992). Çalışmamızda meşe topraklarının $\mathrm{CaCO}_{3}$ ve $\mathrm{Ca}$ değerleri karaçam topraklarından önemli düzeyde yüksektir.

Meşe topraklarında $\mathrm{P}_{2} \mathrm{O}_{5}$ miktarı karaçam topraklarına göre önemli düzeyde yüksektir. Organik fosfor bileşiklerinin ayrışmasında ve mineralizasyonunda toprakta yaşayan mikroorganizmaların etkisi büyüktür; uygun $\mathrm{pH}$ derecelerinde mikroorganizmalar tarafından önemli miktarda organik fosfor bileşiği mineralize edilmektedir (Kantarcı, 2000). Araştırmamızda meşenin hâkim olduğu topraklarda $\mathrm{P}_{2} \mathrm{O}_{5}$ içeriğinin karaçamdan yüksek olduğu görülmüştür. Meşe altındaki topraklarda pH'nın daha yüksek olmasının topraktaki alınabilir fosfor miktarının bu tür altında daha yoğun olması sonucunu doğurmuş olduğu düşünülmektedir. Ayrıca daha düşük $\mathrm{C} / \mathrm{N}$ oranına sahip meşe topraklarındaki daha yoğun mikrobiyal etkinlik de $\mathrm{P}_{2} \mathrm{O}_{5}$ üretimini destekleyebilir.

Toprak derinliği Cmic/Corg oranını ve $\beta$-D glikosidaz enzim aktivitesini önemli düzeyde etkilemiştir. Alt derinlik kademesinde $\mathrm{Cmic/Corg}$ oranı değerlerinin daha yüksek olduğu belirlenmiştir. $\beta$-D glikosidaz ise meşede bu oranla aynı yönde değişim göstermiş, karaçamda bu enzim aktivitesi değerleri üst toprakta yüksek bulunmuştur. Keza toplam azot, organik madde, yarayışlı fosfor ve elektriksel iletkenlik de üst topraklarda önemli düzeyde yüksektir.

Sonuç olarak, araştırmamızda karaçam-meşe sahasında çıkan yangının toprak özelliklerini önemli ölçüde olumsuz etkilemediği, aksine yarayışlı formda besin maddelerini artırdığ $1\left(\mathrm{P}_{2} \mathrm{O}_{5}, \mathrm{Ca}\right)$ ve organik maddede önemsiz düzeyde azalmaya neden olduğu tespit edilmiştir. Bu sonucun çalışma sahamızda karaçamın yanında meşenin de bulun- ması ve yangın şiddetinin düşük olmasından kaynaklandığ 1 düşünülmektedir. Saf meşcerelere göre karışık karaçam meşcerelerinde yangın sonrası olumsuz etkilerin daha az görüldüğü bilinmektedir (Pausas ve ark., 2008). Bu nedenle bu sahamızda herhangi bir 1slah tedbiri önerilmesi gerekli değildir. Yangından sonra toprağı 1slah tedbirlerinin belirlenmesi ile ilgili hususlar bu çalışmanın kapsamı dışındadır.

Araştırma sahamızda yangın sadece 5 ha alanda etkili olmuş ve yayılmamıştır. Yangın sonrası sahada gençlik yeterli olduğundan sahada tohum takviyesi ya da dikim yapılmamıştır. Bu saha yukarıda zikredilen tedbirlerin alınmasını gerektirmemektedir. Ancak düşük ve orta şiddette cereyan eden bu yangın sonucu sağlanan bulgular ölü örtü ve yanıcı materyal birikiminin fazla olduğu sahalarda denetimli yangınların kullanımının yaygınlaştırılmasına yönelik çalışmaların faydalı olduğunu destekler niteliktedir.

Uygulamanın etkisine bakıldığında ise toprak özellikleri bakımından yanan ağaç enkazın kaldırılmasının önemli bir fark yaratmadığ 1 ve sakıncasının bulunmadığı söylenebilir. Anayasa ve mevzuat gereği yanan ormanların yerinde yeni orman yetiştirilir. Nitekim uygulamada bir yıl içerisinde yeni orman yetiştirilmesi çalışmalarına başlanmaktadır. Ancak çeşitli çalışmalar yanan sahada yapılan boşaltma çalışmalarının erozyonu teşvik edici yönüne değinmiştir. Düşük şiddetli yangınların sıcaklık yüksek derecelere çıkmadığı ve buharlaşma yoluyla besin kaybı yaşanmadığ 1 için bazı faydalı etkileri olmakla beraber bu yangınlar hidrofobik kül oluşumuna yol açabilir ve hidrofobik bileşikler y1kanıncaya kadar toprağa suyu geçirmezlik özelliği katabilir (Pereira ve ark., 2018). Çalışmamızdaki gibi çok eğimli yamaç arazilerde yangının şiddetine, erozyon riskine, böcek zararı tehlikesine ve türe bağlı olarak sahanın boşaltılmasının ertelenmesi ve mevzuatın yapılacak benzer araştırmalarla desteklenerek geliştirilmesi faydalı olacaktır.

Karaçam tohumlarının sıcaklığa hassas olduğu ve gençleşme yeteneğinin düşük olduğu düşünüldügünde küresel isınmayla bu meşcerelerde artan orman yangınlarının etkisinin tam olarak anlaşılması için saf ve karışık karaçam meşcerelerinde toprak biyolojik parametrelerini de içeren çalışmalar artırilmalidir.

\section{Teşekkür}

Bu çalışma ESK-11 (6300)/2011-2015 numaralı proje kapsamında Orman Genel Müdürlüğü, Orman Toprak ve Ekoloji Araştırma Enstitüsü Müdürlüğü tarafından desteklenmiştir. 


\section{Kaynaklar}

Acosta-Martinez, V., Tabatabai, M.A. 2000. Enzyme activities in a limed agricultural soil. Biology and Fertility of Soils, 31: 85-91

Adams, P.W., Boyle, J.R. 1980. Effects of fire on soil nutrients in clearcut and whole-tree harvest sites in Central Michigan. Soil Science Society of America Journal, 44: 847-850

Akburak, S., Son, Y., Makineci, E., Çakır, M. 2017. Impacts of low-intensity prescribed fire on microbial and chemical properties in a Quercus frainetto forest. Journal of Forestry Research, 29: 687-696.

Anon, 2014a. Keys to Soil Taxonomy Twelfth ed. NRSC (Natural Resources Conservation Service), United States Department of Agriculture

Anon, 2014b. World reference base for soil resources (International soil classification system for naming soils and creating legends for soil maps), FAO, 181, Rome

Barnes, B.V., Zak, D.R., Denton, S.R., Spurr, S.H. 1998. Forest Ecology, Fourth Edition, John Wiley and Sons, New York

Barreiro, A., Lombao, A., Martín, A., Carballas, T., Fonturbel, M.T., Vega, J.A., Fernández, C., Díaz-Raviña, M. 2015. Short-term effects of a wildfire on soil properties in Fragas do Eume Natural Park (Galicia, NW Spain), FLAMMA, 6(2): 61-64.

Beier, C., Blanck, K., Bredemeier, M., Lamersdorf, N., Rasmussen, L. 1998. Responses of soil and vegetation to reduced input of $\mathrm{S}, \mathrm{N}$ and acidity to two Norway spruce stands of the EXMAN Project, Forest Ecology and Management, 101: 111-123.

Bentley, J. R., Fenner, R. L. 1958. Soil temperatures during burning related to post fire seedbeds on woodland range. Journal of Forest Research, 56: 737-740

Berber, A. S., Tavşanoğlu, Ç. ve Turgay, O.C. 2015. Effects of surface fire on soil properties in a mixed chesnut-beech-pine forest in Turkey. FLAMMA, 6(2): 78-80 (In press)

Bergkvist, B., Folkeson, L., 1995. The influence of tree species on acid deposition proton budgets and element fluxes in South Swedish forest ecosystems, Ecological Bulletin, 44: 90-99

Bilgili, E. 2009. Wildland Fires, Forest Ecosystems and Soils. 2nd International meeting of Fire Effects on Soil Properties, February 11-15, Marmaris, Turkey.

Blank, R.R., Zamudio, D.C. 1998. The influence of wildfire on aqueous-extractable soil solutes in forested and wet meadow ecosystems along the eastern front of the Sierra-Nevada Range, California. International Journal of Wildland Fire, 8: 79-85
Boerner, R.E.J., Decker, K.L.M., Sutherland, E.K. 2000. Prescribed burning effects on soil enzyme activity in a southern Ohio hardwood forest: a landscape-scale analysis. Soil Biology and Biochemistry, 32: 899-908

Boerner, R.E.J., Brinkman J.A., Smith A. 2005. Seasonal variations in enzzyme activity and organic carbon in soil of a burned and unburned hardwood forest. Soil Biology and Biochemistry, 37: 1419-1426

Boydak, M., Eler, Ü., Pehlivan, N. 1996. Antalya-Elmalı Yöresi Sedirlerinin (Cedrus libani Rich.) Gençleştirilmesinde Denetimli Yakma ve Diğer bazı Faktörlerin Başarı Üzerine Etkileri. Batı Akdeniz Araştırma Müdürlüğü, Teknik Rapor, No:2, 42s, Antalya

Brady, N.C., Weil, R.R. 1999. The Nature and Properties of Soils, Twelfth Edition, Prentice Hall, Upper Saddle River, New Jersey

Brookes, P.C. 1995. The use of microbial parameters in monitoring soil pollution by heavy metals. Biology and Fertility of Soils, 19: 269-279

Caon L., Vallejo V.R., Coen R.J., Geissen V., 2014. Effects of wildfire on soil nutrients in Mediterranean ecosystems. Earth Science Reviews, 139:47-58

Certini G., 2005. Effects of fire on properties of forest soils: a review. Oecologia, 143: 1-10.

Certini G., 2013. Fire as soil-forming factor. Ambio, 43: 191-195

Clarholm, M. 1993. Microbial biomass P, labile P, and acid phosphatase activity in the humus layer of a spruce forest, after repeated additions of fertilizer. Biology and Fertility of Soils, 8: 128-133

Çepel, N. 1975. Orman yangınlarının mikroklima ve toprak özellikleri üzerine yaptığ $\breve{1}_{1}$ etkiler. İstanbul Üniversitesi. Orman Fakültesi Dergisi, Seri B, Cilt XXV, $1,71-93$

Eivasi, F., Bayan, M.R. 1996. Effects of long-term prescribed burning on the activity of selected soil enzymes in an oak-hickory forest. Canadian Journal of Forest Research, 26: 1799-1804.

Eriksson, E., Karltun, E., Lundmark, J.E, 1992. Acidification of forest soils in Sweden, Ambiology, 21: 150-154.

Ergene, A., 1997. Toprak Biliminin Esasları, Genişletilmiş Yedinci Baskı, 0027, Öz Eğitim Basım Yayın Dağ1tım Ltd. Şti., Konya.

Eron, Z. 1977. Heating effects on forest soil physical properties and subsequent seedling growth. Ph. D., University of Montana.

Eron, Z. ve Gürbüzer, E. 1988. Marmaris 1979 Y11 Orman Yangını ile Toprak Özelliklerinin Değişimi ve Kızılçam Gençliğinin Gelişimi Arasındaki İlişkiler. Ormancılık Araştırma Enstitüsü, Teknik Bülten, Ankara. 
Esquilin, A.E.J., Stromberger, M.E., Shepperd W.D. 2008. Soil scarification and wildfire interactions and effects on microbial communities and carbon. Soil Science Society of America Journal, 72:111-118.

Etiegni, L., Campbell, A.G. 1991. Physical and chemical characteristics of wood ash. Bioresource Technology, 37: 173-178.

Fisher, R., Binkley, D. 2000. Ecology and Management of Forest Soils, John Wiley\&Sons, Inc., 241-261, USA

Fitzpatric, E.A. 1986. An Introduction to Soil Science, Second Edition, Longman Scientific and Technical, John Wiley and Sons, New York.

Foth, H.D., 1990. Fundamentals of Soil Science, Eighth Edition, John Wiley and Sons.

Francos, M., Úbeda, X., Pereira, P., Alcaniz, M., 2018. Long-term impacts of wildfire on soils exposed to different fire severities. A case study in Cadiretes Massif (NE Iberian Peninsula). Science of the Total Environement, 615:664-671.

Goforth B.R., Graham R.C., Hubbert K.R., Zanner, C.W., Minnich, R.A., 2005. Spatial distribution and properties of ash and thermally altered soils after high-severity forest fire, southern California. International Journal of Wildland Fire, 14: 343-354.

Gülçur, F. 1974. Toprağın Fiziksel ve Kimyasal Analiz Metodlar1. İstanbul Üniversitesi Orman Fakültesi Yayınlar1, 1970, 201-225, İstanbul.

Gürlevik, N., Özkan, K., Gülcü, S. (2009). Effects of prescribed burning and mechanical site preparation on soil properties in a kermes oak field in Isparta region. Turkish Journal of Forestry, A (1): 24-37.

Hernandez, T., Garcia, C., Reinhardt, I., 1997. Shortterm effect of wildfire on the chemical, biochemical and microbiological properties of Mediterranean pine forest soil. Biology and Fertility of Soils, 25 (2):109-116.

Hoffman, G., Teicher, K. 1961. Ein kolorimetrisches verfahren zur bestimmung der ureaseaktivitat in boden. Zeitschrift für Pflanzenernährung, Düngung, Bodenkunde, 95 (1): 55-63.

Irmak, A. 1953. Arazide ve Laboratuarda toprağın Araştırılması Metodları. İ.Ü. Orman Fak. Yayınları, No:27, İstanbul.

Jackson, M.L., 1962. Soil Chemical Analysis. PrenticeHall, inc. N.J.

Kaçar, B., 2009. Amunyum Asetat Metodu, Toprak Analizleri, Nobel Yayın Dağıtım, Nobel Yayın No: 1387, Genişletilmiş 2. Basım, 467 s., Ankara.

Kantarc1, M.D., Parlakdağ, S., Pehlivan, N., 1986. Sedir Ormanlarının Gençleştirilmesinde Yangın Kültürü ve Ekolojik Yorum, İ.Ü. Orman Fakültesi Dergisi, 36(2):
20-39.

Kantarc1, M.D., 2000. Toprak İlmi, İstanbul Üniversitesi Orman Fakültesi Yayınlar1, 4261, İstanbul.

Kara, Ö., Bolat, I. 2009. Short-term effects of wildfire on microbial biomass and abundance in black pine plantation soils in Turkey. Ecological Indicators, 9: 1151-1155.

Karaca, A., Çetin, S.C., Turgay, O.C., Kızılkaya, R. 2011. Soil enzymes as indication of soil quality. In Soil Enzymology, Shukla G. and Varma A. (eds.). Soil Biology 22, Springer, 119-149.

Khanna, P.K., Raison, R.J., 1986 Effect of fire intensity on solution chemistry of surface soilunder a Eucalyptus pauciflora forest. Australian Journal of Soil Research, 24: $423-434$.

Khanna, P.K., Raison, R.J., Falkiner, R.A. 1994. Chemical properties of ash derived from Eucalyptus litter and its effects on forest soils. Forest Ecology Management, 66: $107-125$.

Klemmedson, J.O. 1992. Decomposition and nutrient release from mixtures of Gambel oak and Panderosa pine. Forest Ecology and Management, 47(1-4): 349-361.

Kutiel, P., Shaviv, A., 1992. Effects of soil type, plant composition and leaching on soil Nutrients following a simulated forest fire. Forest Ecology and Management, 53: 329-343

Küçük, M. 2006. Genç karaçam meşcerelerinde yang1nın toprak solunumu, kök kütlesi ve toprağın fiziksel ve kimyasal özellikleri üzerine etkileri. Artvin Çoruh Üniversitesi Fen Bilimleri Enstitüsü, Yüksek Lisans Tezi, 61s, Artvin.

Ludwig, B., Khanna, P.K., Raison, R.J., Jacobsen, K.L. 1998. Modelling cation composition of soil extracts under ashbeds following an intense slashfire in a eucalypt forest. Forest Ecology and Management, 103: 9-20.

Miller, R.W., Donahue, R.L., 1990. Soils, Sixth Edition, Prentice Hall, Englewood Cliffs, New Jersey.

Naseby, D.C., Lynch, J.M. 1997. Rhizopshere soil enzymes as indicators of perturbation caused by enzyme substrate addition and inoculation of a genetically modified strain of Pseudomonas fluorescens on wheat seed. Soil Biology and Biochemistry, 29:1353-1362.

Neyisçi, T. 1989. Kızılçam orman ekosistemlerinde denetimli yakmanın toprak kimyasal özellikleri ve fidan gelişimi üzerine etkileri. Ormancılık Araştırma Enstitüsü Yayınları Teknik Bülten Serisi, 205, Ankara.

Neyişçi, T., Şirin, G. ve Sarıbaşak, H. 2002. Batı Akdeniz Bölgesinde orman yangını tehlikesinin düşürülmesinde denetimli yakma tekniğinin uygulanma olanaklar1. Türkiye Ormancılar Derneği Yayını, 2, Ankara.

Özdamar, K., 2004. Paket Programlar ile İstaistiksel 
Veri Analizi-1, 5.Bask1, Kaan Kitabevi, 649, Eskișehir

Pausas, J.G., Lllovet, J., Rodrigo, A. and Vallejo, R. 2008. Are wildfires a disaster in the Mediterranian Basin?-A Review. International Journal of Wildland Fire, 17: 713-723

Pereira, P., Francos, M., Brevik, E.C., Ubeda, X., Bogunovic, 2008. I. Post fire management. Current Opinion in Environmental Science and Health (In press)

Richards, L.A., 1954. Diagnosis and Improvement of Saline and Alkaline Soils (Agricultural Handbook No. 60). US Salinity Laboratory. USDA. 159, Washington

Saa, A., Trasar-Cepeda, M.C., Gil-Sotres, F., Carballas, T. 1993. Changes in soil phosphorus and acid phosphatase activity immediately following forest fires. Soil Biology and Biochemistry, 25: 1223-1230

Sarıyıldız T., 2004. Toprak asitliği üzerinde ağaç türleri, tepe yapıları ve mevsimlerin etkisi. Kafkas Üniversitesi, Artvin Orman Fakültesi Dergisi, 3-4: 220-231

Simard, D.G., Fyles, J.W., Pare', D., Nguyen, T. 2001. Impacts of clearcut harvesting and wildfire on soil nutrient status in the Quebec boreal forest. Canadian Journal of Soil Science, 81: 229-237

Tavşanoğlu, Ç. and Gürkan, B. (2010). Physical and chemical properties of the soils at burned and unburned Pinus brutia Ten. forest sites in the Marmaris region. Hacettepe Journal of Biological Chemistry, 38: 71-76.
Tomkins, I.B., Kellas, J.D., Tolhurst, K.G. and Oswin, D.A. 1991. Effects of fire intensity on soil chemistry in a eucalypt (Eucalyptus sp.) forest. Australian Journal of Soil Research, 29: 25-47

Turgay, O.C., Lumbanraja, J., Yusnaini, S., Nonaka, M., 2002. Effect of land degradation on soil microbial biomass in a hilly area of south Sumatra, Indonesia. Soil Science Plant Nutrition, 48(5): 769-774

Ulery. A.L., Graham. R.C., Amrhein. C., 1993. Woodash composition and soil $\mathrm{pH}$ following intense burning Soil Science, 156: 358-364

Ülgen, N., Ateşalp, M., 1972. Toprakta Bitki Tarafından Alınabilir Fosfor Tayini, Köy İşleri Bakanlığı, Toprak Su Genel Müdürlüğü, Toprak ve Gübre Araştırma Enstitüsü, Teknik Yayınlar, Sayı 21, Ankara

Vance, E.D., Brookes, P.C., Jenkinson, D.S. 1987. An extraction method for measuring soil microbial biomass. Soil Biology and Biochemistry, 19: 703-707

Woodwell, G.M., Whittaker, R.H. and Hoghton, R.A. 1975. Nutrient concentrations in plants in the Brookhaven oak-pine forest. Ecology, 56: 318-332

Y1ldı, O., Esen, D., Sargınc1, M., Toprak, B. 2010. Effects of forest fire on soil nutrients in Turkish pine (Pinus brutia, Ten) Ecosystems. Journal of Environmental Biology, 31: 11-13 